Gabriel M. Ahlfeldt* \& Daniel P. McMillen^

\title{
Tall Buildings and Land Values: Height and Construction Cost Elasticities in Chicago, 1870 - 2010*
}

\begin{abstract}
Cities around the world are experiencing unprecedented vertical growth. Yet, the economics of skyscrapers remain empirically understudied. This paper analyzes the determinants of the urban height profile by combining a micro-geographic data set on tall buildings with a unique panel of land prices covering 140 years. We provide novel estimates of the land price elasticity of height, the height elasticity of construction cost, and the elasticity of substitution between land and capital for tall buildings. In line with improvements in construction technology, the land price elasticity of height increased substantially over time, rationalizing a trend to ever taller buildings. The land price elasticity of height is larger for commercial than for residential buildings, suggesting that the typical segregation of land uses within cities is not exclusively shaped by the demand side, but also by the supply side.
\end{abstract}

Keywords: Chicago, construction cost, density, height, land value, skyscraper

JEL: R20, R30

Version: September 2017

* London School of Economics and Political Sciences (LSE) and Centre for Economic Policy Research (CEPR), Houghton Street, London WC2A 2AE, g.ahlfeldt@lse.ac.uk, www.ahlfeldt.com

- University of Illinois at Urbana-Champaign, Department of Economics, 214 DKH, 1407 W. Gregory Dr., Urbana, IL 61801, mcmillen@illinois.edu.

* We thank the Lincoln Institute of Land Policy and especially Joan Youngman and Semida Munteanu for generous funding and support. We are also grateful to the Center for Metropolitan Studies, especially Dorothee Brantz, for hosting a team of researchers during the project work. We thank seminar and conference participants in Barcelona, Potsdam, Toronto, and Washington D.C. and in particular Rainald Borck, Christian Hilber, Paul Cheshire, Henry Overman, Olmo Silva, Stuart Rosenthal, and Will Strange for comments and suggestions. Kristoffer Moeller and Sevrin Weights are acknowledged for their great contribution to designing and coordinating the compilation of the land price data set. Ted Pinchbeck is acknowledged for help with the skyscraper data set. Philip Boos, Aline Delatte, Nuria-Maria Hoyer Sepulvedra, Devika Kakkar, Rene Kreichauf, Maike Rackwitz, Lea Siebert, Stefan Tornack, Tzvetelina Tzvetkova provided excellent research assistance. 


\section{Introduction}

Iconic metropolitan skylines, the widely visible signs of demand for density and economic success of cities, are growing at an unprecedented rate. The past decade has seen the completion of 650 skyscrapers exceeding 200 meters. In 2015 alone, a record number of 106 tall buildings over 200 meters has been completed and this number is predicted to increase to 135 in 2016 . From 2010 to 2015 the number of super-tall buildings exceeding 300 meters has doubled from 50 to $100 .^{1}$ The 830 meter-tall Burj Khalifa set an impressive new record for the tallest structure in the world. This vertical growth is particularly impressive considering the sizable cost of supplying space in tall commercial and residential buildings. The construction of the Burj Khalifa came at a cost of $\$ 1.5$ billion (Long, 2011). One World Trade Center, not as tall but heavily reinforced to withstand terrorist attacks, cost as much as $\$ 3.8$ billion (Brown, 2012). These costs are excessive even considering that some tall buildings can host the equivalent of a small town. ${ }^{2}$ The per floor space construction cost of a 50 -floor building is about three times that of a 10-floor building, with costs increasing exponentially in height. ${ }^{3}$

It is, therefore, perhaps not surprising that skyscrapers are often claimed to be not economically viable (Tauranac, 1995) and instead physical manifestations of irrational growth expectations (Lawrence, 1999), although this claim is not substantiated by careful statistical tests (e.g., Barr et al, 2015). Skyscrapers offer economic benefits to owners, occupiers and developers. Skyscrapers allow firms to place vast numbers of workers at the most productive locations, usually the densest places (Ahlfeldt et al., 2015) that attract the most productive people (Combes et al., 2012). Skyscrapers further add to these locations by increasing economic activity, which makes them both a cause and an effect of density. It is intuitive that if firms are willing to pay sufficiently high rents to be located at very productive locations, the construction of very tall buildings will be profitable even if construction costs are high. The existence of skylines can be rationalized by high land prices and substitution away from a scarce and expensive factor - land - as predicted by neoclassical theory (Brueckner, 1987; Mills, 1967; Muth, 1969). Notably, the most vertical cities such as New York and Hong Kong also tend to be among the most expensive cities.

1 All statistics are from the Global Tall Building Database of the Council on Tall Buildings and Urban Habitat (www.skyscrapercenter.com)

2 Large skyscrapers host several tens of thousands of workers (www.nysm.nysed.gov/wtc/about/facts.html).

3 Own calculation based on the results reported in Table 6. 
Economists have for long largely ignored the existence of skyscrapers, leaving the driving forces that determine the verticality of cities empirically understudied. ${ }^{4}$ This gap in the literature is not only surprising and dissatisfactory due to the sheer size of the investments involved, but also because of their longevity. Worldwide, $98 \%$ of buildings exceeding 100 meters survived their $50^{\text {th }}$ anniversary. For skyscrapers, the figure is as high as $99.4 \% .^{5}$ And so far, no super-tall building has ever been demolished. Hardly any other form of capital is as durable, implying that any decision to build a skyscraper will likely have a legacy on the spatial structure of a city.

In this paper, we provide a novel analysis of the determinants of the urban height profile. We argue that skyscrapers are rational responses to high land prices that result from high demand for productivity advantages and amenities that dense clusters such as central business districts offer. We identify three components that affect the elasticity of building height with respect to land price. First, the height elasticity depends on the elasticity of substitution between land and capital (Ahlfeldt and McMillen, 2014; Epple et al., 2010). The easier it is to substitute away from the use of land in the provision of the building services that residential and commercial users demand, the more rapidly will developers respond to increases in land prices by piling up floor space and building tall. Second, the height elasticity depends on the convexity of the construction cost function. If the per-unit cost of providing space increases rapidly in building height (due to more sophisticated structural engineering and materials), the height response to increases in land prices will be mitigated. Third, the height elasticity depends on the degree to which taller high-rise structures require the provision of larger surrounding "extra spaces", be it to facilitate construction, accommodate amenities, or due to zoning regulations. Developers normally respond to increases in land price by providing more space per land unit and building taller. If the required extra space increases in building height, a smaller fraction of the property will be occupied by a tall structure. This creates a pressure to build even taller to achieve the desired amount of space per land unit.

To analyze the urban height profile, we construct a novel micro-geographic data set with quasi-temporal variation. Our core data set includes about 1,750 constructions of tall buildings in Chicago (including buildings that have been demolished) for which we know the exact location, the height, and

4 Liu et al. (2015) provide recent estimates of the internal rent gradient. The evidence on determinants of building heights is confined to Jason Barr's work, which is reviewed in the next section.

5 For longer periods the survival rate increases further because the demolition rate is highest for tall buildings constructed in the 1940 s to 1970 s. 
the construction year. Using a variety of data sources, we combine these data with a unique panel of spatially disaggregated land prices, covering the whole of Chicago from 1873 onward. Matching land prices to tall buildings based on location and construction year allows us to capture the economic conditions at the time when the decisions to construct these buildings were made. For a subset of buildings, our data set includes information on the size of the land parcel, the building footprint, and the cost of construction. In addition to its reputation as a city that closely matches the features of the stylized Alonso-Muth-Mills model (Alonso, 1964; Mills, 1967; Muth, 1969), Chicago is a particularly interesting case for our study because it has a long history of innovative architecture and an unusually high concentration of tall buildings. Its relatively lax zoning code presents few restrictions on the construction of tall buildings in prime areas.

We use this combination of data sets to gain insights into the determinants and the nature of skylines. We provide a series of novel estimates of parameters that determine the verticality of cities. We estimate an elasticity of height with respect to land price of $45 \%$ for commercial buildings and $30 \%$ for residential buildings in 2000. Over 100 years, the elasticity approximately doubled, which is in line with significant improvements in construction technology as well as a shift towards a less rigid zoning regime. We also provide estimates of the elasticity of per floor space construction cost with respect to height, which ranges from $25 \%$ for small buildings to well above unity for super-tall buildings and is generally larger for residential than for commercial buildings. Our estimates of the elasticity of extra space with respect to height range from $10 \%$ to $15 \%$. Combining these estimates, we infer the first estimates of the elasticity of substitution between land and capital for tall commercial (77\%) and tall residential (48\%) buildings. Our estimates for tall buildings are smaller than the about-unity estimates recently found for small residential structures in Chicago (Ahlfeldt and McMillen, 2014), suggesting that the elasticity of substitution may not be constant.

The results of our analysis of the determinants of the vertical structure have important implications for the horizontal land use pattern of cities. The land price elasticity of height is larger for commercial than for residential buildings because the elasticity of substitution between land and capital is larger and the height elasticity of construction cost is lower. In other words, it is easier to pile up offices than homes. The strong tendency for commercial activities to concentrate in central business districts, subcenters, or edge cities is typically attributed to demand-side factors such as agglomeration economies (Ahlfeldt et al., 2015; Fujita and Ogawa, 1982; Lucas and Rossi-Hansberg, 2002). Our results suggest that the supply side also plays an important role in explaining the high degree of spatial concentration of commercial activity and the sharp segregation of land uses that is characteristic for many cities. 
The remainder of the paper is organized as follows. Section 2 introduces the related literature, some context, and our data. We introduce our empirical strategy in section 3 and present the results in section 4. Section 5 concludes the paper.

\section{Background and data}

\subsection{Related literature}

While skyscrapers represent a striking and widely visible form of extreme urbanization, they have attracted relatively limited attention in economics research. The theoretical literature has analyzed the relationship between building height and agglomeration (Grimaud, 1989; Helsley and Strange, 2007), as well as building height and between- and within-building transport cost (Sullivan, 1991). Helsley and Strange (2008) introduce an intrinsic value of being the tallest in a game-theoretical analysis to rationalize why skyscrapers are developed beyond what appears to be a fundamentally efficient height. ${ }^{6}$ Empirically, a number of studies have found that rents tend to be relatively high in tall office buildings (Colwell et al., 1998; Koster et al., 2014; Liu et al., 2015; Shilton and Zaccaria, 1994), with the notable exception of Eichholtz et al. (2008), who find mixed results. Liu et al. (2015) present evidence of a rent gradient within tall buildings, with particularly high premiums near the top of a building.

Solid empirical evidence on the determinants of building heights is particularly scarce. Clark and Kingston (1930) provide an early attempt to relate skyscraper height to economic fundamentals. More recent evidence is essentially confined to Jason Barr's work on tall building structures in Manhattan. ${ }^{7}$ Barr (2010) provides a time-series analysis of building height, which suggests that skyscraper height is mainly determined by economic fundamentals. Barr (2012) finds a spatial auto-regressive structure in building heights, which he interprets as evidence for builders engaging in height competition. Barr (2013) analyzes the skyscraper competition between New York and Chicago. Barr et al. (2010) show that the availability of solid bedrock influences where skyscrapers are developed within business dis-

6 A broadly related literature has analzed the cost of building height restrictions theoretically (Arnott and MacKinnon, 1977; Bertaud and Brueckner, 2005).

7 Cheshire and Derricks (2014) show that employing an award-winning architect allows developers to negotiate the right to build taller in London, UK. 
tricts, but not the locations of business districts themselves. Compared to these studies, the main advantage of our data set is that we observe the price of land at the location and time when decisions on building heights were made for virtually all tall buildings in Chicago.

Our research is related to a number of broader strands in the urban economics literature. In particular, we contribute to the literature on the substitution of land for capital in the production process for housing (Ahlfeldt and McMillen, 2014; Albouy and Ehrlich, 2012; Epple et al., 2010; McDonald, 1981). ${ }^{8}$ Our research is also closely related to studies that have analyzed building density (Barr and Cohen, 2014; McMillen, 2006) and land price (Ahlfeldt and Wendland, 2011; McMillen, 1996) gradients. The study is also related to empirical analyses of spatial competition (Brueckner, 2003; Brueckner and Saavedra, 2001) and the literature on the effects of very high densities and localized agglomeration (Ahlfeldt et al., 2015; Arzaghi and Henderson, 2008). ${ }^{9}$ Not least, by providing novel estimates of the rate at which construction costs increase in height, we contribute to a small literature that mainly consists of theoretical analysis and engineering estimates (Lee et al., 2011; Tan, 1999).

\subsection{Building heights}

The major component of our data was acquired from Emporis.com, a commercial data provider that collects technical information on various types of buildings, including skyscrapers, high-rises, and various structures such as halls or stadiums. The data base is considered the most complete data base on tall structures to date, and has been used in various analyses of the Manhattan skyline (Barr, 2010, 2012, 2013; Barr and Cohen, 2014; Barr et al., 2010). The data includes buildings that have been torn down, making a potential selection bias due to a higher teardown probability of smaller structures less likely.

8 Research into the supply side of the urban economy goes back to Mills (1967) and Muth (1969).

9 Examples of more aggregated analyses include Ciccone (2002), Ciccone and Hall (1996), Dekle \& Eaton (1999), Glaeser and Mare (2001), Henderson, Kuncoro and Turner (1995), Moretti (2004), Rauch (1993), and Sveikauskas (1975). 


\section{Fig. 1. Location of tall buildings by construction date cohort}

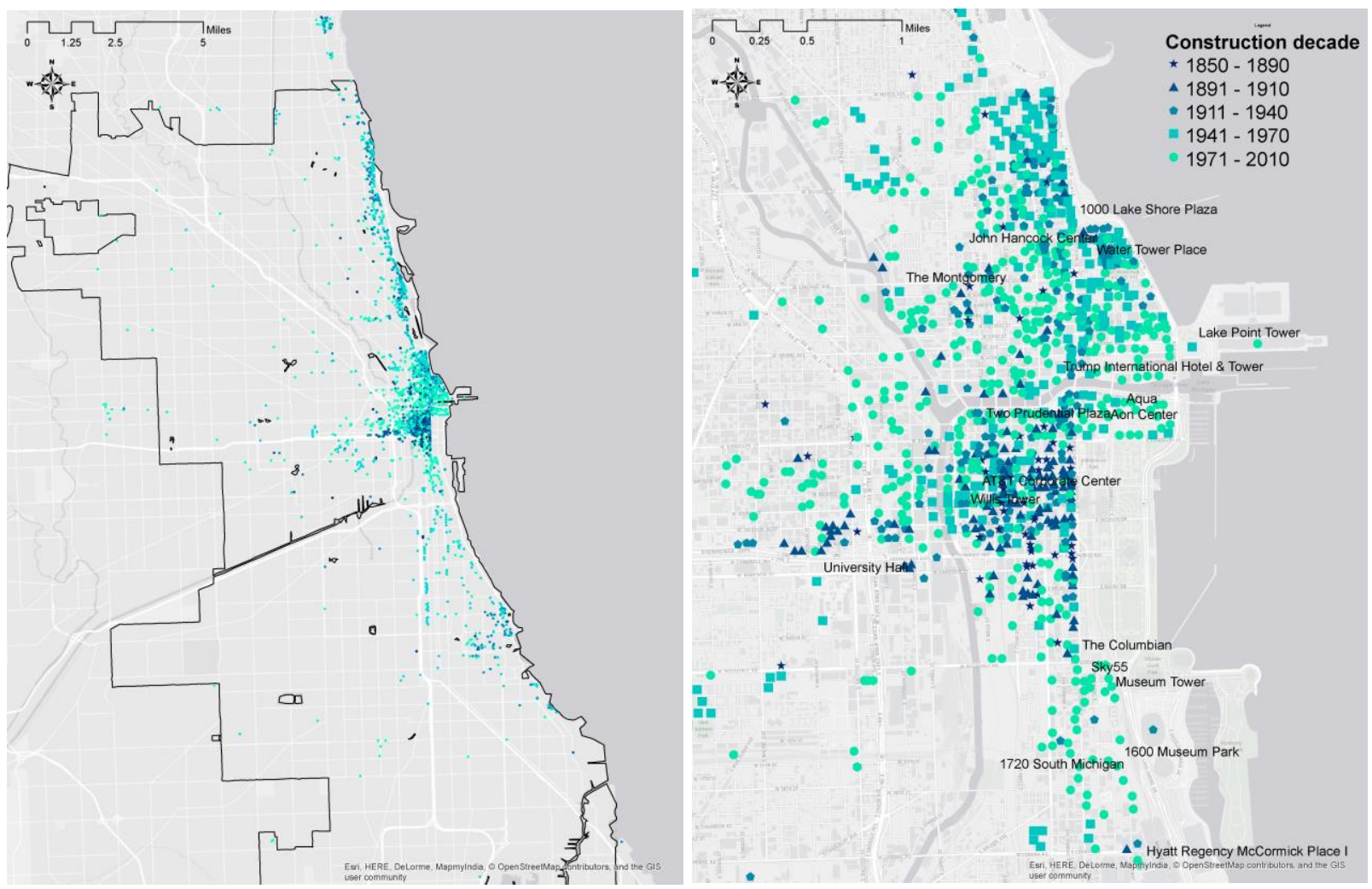

Notes: Own illustration based on (c) Emporis.com and base maps from @ O OpenStreetMap, accessed via the ESRI ArcGIS Online service.

From this world-wide database, we extract information on the construction of buildings in Chicago with at least five floors and with complete information on the exact location (geographic coordinates), the year of construction, and a measure of building height. ${ }^{10}$ In our analysis, we normally use the architectural height of a building, which excludes antenna masts. For a handful of buildings with missing data, we use regressions of height on the number of floors to impute heights. Within the area covered by our land price data (discussed in the next subsection), we have 1,737 tall buildings, whose location we plot in Figure 1. Despite the long time frame, only 4.4\% (77) of these tall buildings had been demolished by 2014. As expected, the vast majority of tall buildings are located near Lake Michigan and, in particular, the central downtown sections of the city. The earliest construction of tall buildings occurred within the Loop, west of Grant Park.

${ }^{10}$ As we restrict the sample to observations for which construction years are available, some planned but neverbuilt projects drop out. The most impressive is Frank Lloyd Wright's plan for a one-mile tall mega-skyscraper called the Illinois Building. 
Table 1 presents descriptive statistics by construction date cohorts. We generally define cohorts as buildings constructed within a given decade. The exceptions are cohorts defined for the 1870s and 1880 s as well as the 1890s and 1900s because data on constructions is sparse and there is only one cross-section of land prices available in each case. Construction activity of tall buildings has tended to increase over time, although the 1920 s show almost as much new construction as the 2000s. The mean heights of the constructed buildings in our data have approximately doubled over the nearly one and a half century covered by our data set. From the 1920s onward, residential use has replaced commercial as the primary use of tall buildings, which is consistent with the increasingly less centralized location of new buildings. From the 1950s onward, there is a trend for the construction of tall buildings to be more centrally located in the city.

\section{Tab. 1. Descriptive statistics of building constructions}

\begin{tabular}{|c|c|c|c|c|c|c|c|}
\hline \multirow[b]{2}{*}{$\begin{array}{l}\text { Construction } \\
\text { date cohort } \\
\text { (decades) }\end{array}$} & \multicolumn{4}{|c|}{ Building height (meters) } & \multicolumn{2}{|c|}{ Land use } & \multirow[b]{2}{*}{$\begin{array}{l}\text { Distance } \\
\text { to CBD } \\
\text { (miles) }\end{array}$} \\
\hline & $\mathrm{N}$ & Min & Mean & Max & $\begin{array}{l}\text { Residen- } \\
\text { tial } \\
(0,1)\end{array}$ & $\begin{array}{l}\text { Commer- } \\
\text { cial } \\
(0,1)\end{array}$ & \\
\hline $1870 \mathrm{~s} \& 1880 \mathrm{~s}$ & 17 & 17.64 & 42.13 & 98.15 & 0.18 & 0.53 & 0.81 \\
\hline $1890 \mathrm{~s} \&$ \& 1900s & 90 & 17.64 & 48.82 & 97.54 & 0.30 & 0.46 & 1.12 \\
\hline $1910 \mathrm{~s}$ & 90 & 17.64 & 49.10 & 91.44 & 0.32 & 0.49 & 1.45 \\
\hline $1920 \mathrm{~s}$ & 309 & 17.57 & 56.09 & 173.13 & 0.62 & 0.22 & 3.53 \\
\hline $1930 \mathrm{~s}$ & 66 & 17.64 & 52.87 & 184.41 & 0.68 & 0.20 & 4.19 \\
\hline $1940 \mathrm{~s}$ & 18 & 17.64 & 34.14 & 73.76 & 0.61 & 0.11 & 5.43 \\
\hline $1950 \mathrm{~s}$ & 110 & 21.17 & 55.69 & 278.00 & 0.66 & 0.04 & 4.02 \\
\hline $1960 \mathrm{~s}$ & 271 & 17.57 & 73.17 & 344.00 & 0.69 & 0.10 & 3.94 \\
\hline $1970 \mathrm{~s}$ & 167 & 17.64 & 89.78 & 442.00 & 0.70 & 0.19 & 2.97 \\
\hline $1980 \mathrm{~s}$ & 131 & 17.64 & 98.82 & 306.94 & 0.59 & 0.35 & 1.88 \\
\hline 1990s & 99 & 17.64 & 74.36 & 303.28 & 0.56 & 0.17 & 2.67 \\
\hline $2000 \mathrm{~s}$ & 314 & 17.64 & 68.73 & 423.20 & 0.83 & 0.07 & 2.61 \\
\hline $2010 \mathrm{~s}$ & 55 & 17.64 & 92.34 & 249.56 & 0.76 & 0.02 & 1.87 \\
\hline Mean & 133.62 & 17.90 & 64.31 & 235.80 & 0.57 & 0.23 & 2.81 \\
\hline
\end{tabular}

Notes: Data from Emporis.com. 1870 construction date cohort includes all buildings constructed from 1870 to 1889. The 1890 construction date cohort includes all buildings constructed from 1890 to 1909 . All other construction date cohorts are defined for the respective decades. Land use and distances are given as means.

To put this construction activity into perspective, Figure 2 provides a comparison to the tallest buildings in the world at a given time. Up to the 1890s, churches were the tallest structures in the world. At $152 \mathrm{~m}$, the Strasbourg Cathedral was the tallest in the world from 1647 to 1874 after a number of taller churches had collapsed or burned down. In subsequent years, it was replaced by the Church of St. Nicholas (Hamburg, Germany), the Rouen Cathedral (France), the Cologne Cathedral (German) and finally the Ulm Minster (Germany). These tall structures are hard to explain with the canonical urban model, and they suggest that height competition and an intrinsic value of being the tallest is not entirely a recent phenomenon. Similarly, up to the 1870s the tallest buildings in Chicago were churches or structures like water towers that required a certain height to function. This pattern changed in the late 
1890s with the seminal Tacoma Building in Chicago, the first structure in the world using a modern framework of iron and steel. Together with the elevator, which became increasingly common toward the end of the $19^{\text {th }}$ century, the steel frame dramatically reduced the costs of building tall structures. In 1908, the Singer building in New York became the first commercial building to earn the title as the tallest building in the world. Its construction served to jump-start the famous skyscraper race in New York, which culminated in the Empire State Building in the 1930s. Though Chicago was an early entrant in the skyscraper race, it was not until the 1960s that its building heights rivaled New York's. The Willis Tower (formerly the Sears Tower) became the tallest building in the world upon its completion in 1973. Since the 1960s, there has been at least one building exceeding 300 meters constructed in each decade in Chicago, making it one of the most vertical cities of the U.S.

\section{Fig. 2. Tallest constructions by decade}

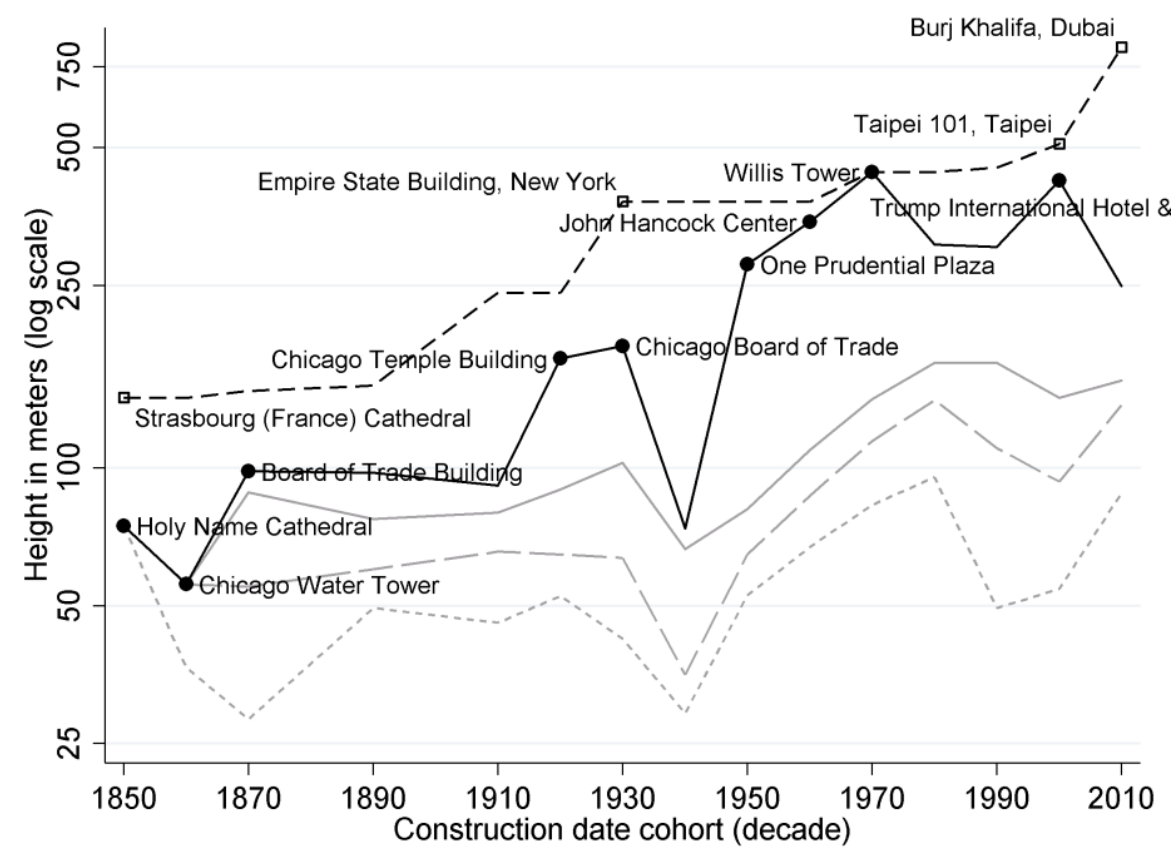

Notes: The dashed black line with squares shows the height of the tallest building in the world in a given decade. The black solid line with circles shows the height of the tallest building constructed in Chicago in a decade. The gray solid (long-dashed) [short-dashed] line shows the $90^{\text {th }}\left(75^{\text {th }}\right)\left[50^{\text {th }}\right]$ percentile in the height distribution of buildings constructed Chicago in a decade.

We note that over the course of our study period, eight different buildings held the title of the tallest in Chicago. On average, these tallest buildings remained in the leading position for slightly more than 20 years, which is perhaps suggestive of overbuilding and dissipative height competition in the spirit of Helsley and Strange (2008)'s model (see appendix section 2 for more information). 


\subsection{Land prices}

Our second main data source is a digitized version of various editions of Olcott's Blue Books of Chicago. Olcott's Blue Books provide front-foot land value estimates for Chicago and many of its suburbs in the form of detailed printed maps. Olcott's land values offer astonishing spatial detail. They typically vary for street segments along the same block, across different sides of the same street, and even take distinct values for corner lots. Olcott's Blue Books are a reputable source from an established assessment company that stayed in business for more than 80 years. Smaller samples of Olcott's land values have previously been used in such studies as Berry (1976), Kau and Sirmans (1979), McDonald and Bowman (1979), McMillen (1996), McMillen and McDonald (2002), Mills (1969), and Yeates (1965). This project is the first to take advantage of a newly digitized version of nine editions ranging from the first edition in 1913 to one of the last editions in 1990, at approximately in 10-year intervals. ${ }^{11}$ The Olcott's data were coded for 330 x 330 feet tracts that closely follow the Chicago grid street structure.

For earlier years we rely on Hoyt (1933), who provides printed land value maps for Chicago in 1873 and 1892. The maps are as detailed as Olcott's maps for the CBD. Outside the downtown area, Hoyt's land values are more aggregated and typically refer to rectangular segments of about a square mile. To enrich the data in the remote areas, we first merge the 1873 and 1892 Hoyt land values to the same 330 x 330 feet grid we created for the Olcott's land values. Using a procedure developed by Cleveland and Devlin (1988), we next run a set of locally weighed regressions using the log of Hoyt's land value estimates for either 1873 or 1892 as the dependent variable and the log of Olcott's 1913 land values as the explanatory variable. Specifically, we run a LWR for each developed grid cell $j$ using kernel weights: $w_{i j}=\exp \left(-\tau^{2} D_{i j}^{2}\right)$, where $D_{i j}$ is the straight-line distance between grid cells $i$ and $j$, and $\tau=0.2$ is a decay parameter that ensures that nearby grid cells receive a higher weight. All grid cells $j$ outside the downtown area that were developed in the given year are then assigned the predicted value from the respective LWR. This procedure ensures that the general spatial price trends follow the 1873 or 1892 Hoyt land values, but incorporate the additional spatial detail provided by Olcott's at the local level. For blocks that were undeveloped in a given year, we assign the predicted value of similar LWR estimates of (log) Hoyt land values on distance from Lake Michigan, the CBD, and geographic coordinates. These LWR estimates serve to smooth the land value surface across the boundaries of the one

11 We collected this data set with the generous financial support of the Lincoln Institute of Land Policy. 
square mile Hoyt land value areas. The collection and processing of the Olcott's and Hoyt raw data is described in more detail in the appendix (section 2).

The final step in the construction of our data set is the addition of data from the Illinois Department of Revenue on sales prices of vacant parcels of land. We employ a similar approach to generate comparable and similarly detailed land values for 2000 and 2010. We run LWR of vacant land transaction prices on $1990(\log )$ Olcott's land values and year effects. For 2000 and 2010, we use a temporal window of \pm 4 years. Again, we run a LWR for each grid cell, in each case weighting all observations (transactions) by the distance from the grid cell, and use the predicted values as our measure of local land value.

This combination of recent vacant land sales, 1913 - 1990 Olcott's data, and our estimates for 1873 and 1892 creates a unique micro-geographic panel data set of 330 x 330 feet grid cells covering virtually the whole of Chicago and 13 cross-sections spanning almost one and a half centuries. Figure 3 compares the estimated land values for 1890 and 2000, when the area within the boundaries of Chicago was already largely developed. Both maps show the typical pattern of land values in Chicago, revealing a clearly monocentric pattern and a large degree of persistency over time. Land prices tend to decline in all directions from the CBD and tend to be higher close to Lake Michigan, which is a natural amenity. The most evident change in the spatial pattern of land prices is a relative increase in land prices in the north compared to the south. 


\section{Fig. 3. Estimated land values}
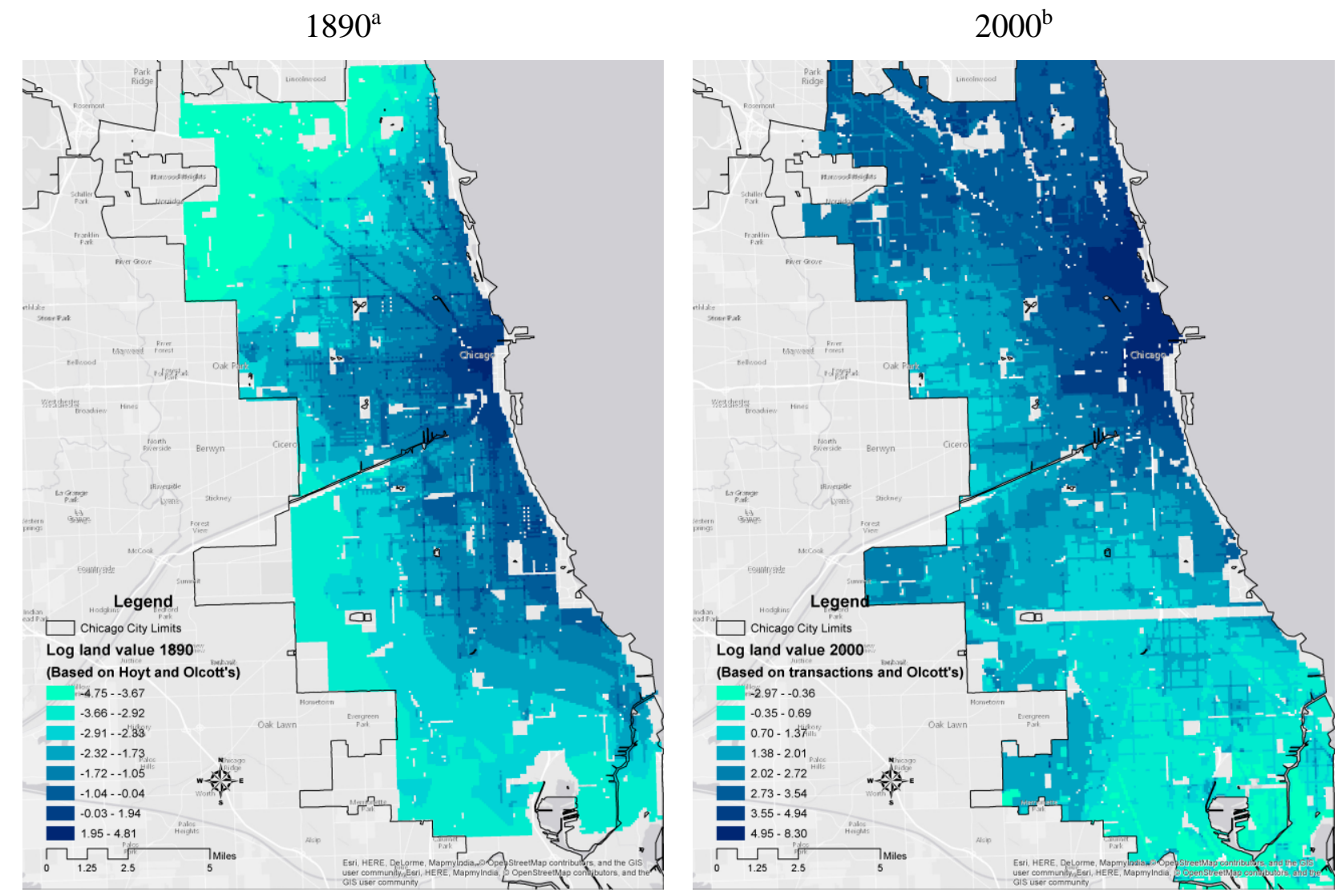

Notes: Base maps from (C) OpenStreetMap, accessed via the ESRI ArcGIS Online service. ${ }^{\text {a }}$ Locally weighted regression interpolation of Hoyt 1 square mile parcels in areas undeveloped in 1890. Predicted values from LWR of Olcott's 1913 on Hoyt 1892 in areas developed in $1890 .{ }^{\mathrm{b}}$ Predicted values from LWR of vacant land prices on 1990 Olcott's.

We then merge this land price panel data set to the data set on tall building constructions described in the previous section. Each building is assigned a land value based on its construction date cohort and the land value grid in which it is located. Table 2 compares the land prices merged to our construction data with the distribution of land prices within the city. As is evident from the table, we have merged land values from roughly the beginning of each decade to the construction date cohorts. The exception is the 1920s, for which data covering the entire area of the city were not accessible to us for years prior to 1926. A comparison of Figures 1 and 3 suggests that tall buildings tend to concentrate in areas with high land prices close to the CBD and Lake Michigan, as predicted by the standard urban model. Indeed, the mean land price merged across new constructions is, on average, more than ten times the mean across grid cells in the city, which reflects the exposed locations of tall buildings. 
Tab. 2. Land prices in the city and in the tall building constructions sample

\begin{tabular}{|c|c|c|c|c|c|c|c|c|c|}
\hline \multirow{2}{*}{$\begin{array}{l}\text { Construction } \\
\text { date cohort } \\
\text { (decades) }\end{array}$} & \multirow{2}{*}{$\begin{array}{l}\text { Land } \\
\text { value } \\
\text { year }\end{array}$} & \multicolumn{5}{|c|}{ All grid cells } & \multicolumn{3}{|c|}{$\begin{array}{l}\text { Grid cells matched } \\
\text { to new constructions }\end{array}$} \\
\hline & & $\mathrm{N}$ & Min & Mean & Max & $\mathrm{N}$ & Min & Mean & Max \\
\hline 1870s \& 1880s & 1873 & 37458 & 0.00 & 0.11 & 21.00 & 17 & 0.13 & 3.93 & 13.50 \\
\hline $1890 \mathrm{~s} \& 1900 \mathrm{~s}$ & 1892 & 37458 & 0.01 & 0.35 & 123.00 & 90 & 0.15 & 29.45 & 123.00 \\
\hline $1910 \mathrm{~s}$ & 1913 & 43324 & 0.01 & 0.52 & 148.33 & 90 & 0.52 & 32.06 & 141.67 \\
\hline $1920 \mathrm{~s}$ & 1926 & 43324 & 0.02 & 1.22 & 206.00 & 309 & 0.11 & 17.66 & 109.00 \\
\hline $1930 \mathrm{~s}$ & 1932 & 43324 & 0.02 & 1.16 & 163.33 & 66 & 0.93 & 12.69 & 100.00 \\
\hline $1940 \mathrm{~s}$ & 1939 & 43324 & 0.00 & 0.58 & 116.35 & 18 & 0.36 & 3.17 & 20.20 \\
\hline $1950 \mathrm{~s}$ & 1949 & 43324 & 0.01 & 0.67 & 145.00 & 110 & 0.11 & 3.14 & 65.00 \\
\hline $1960 \mathrm{~s}$ & 1961 & 43324 & 0.07 & 1.28 & 180.00 & 271 & 0.28 & 5.68 & 86.90 \\
\hline $1970 \mathrm{~s}$ & 1971 & 43324 & 0.30 & 2.20 & 200.00 & 167 & 0.72 & 22.68 & 90.00 \\
\hline $1980 \mathrm{~s}$ & 1981 & 43324 & 0.33 & 2.90 & 250.00 & 131 & 0.80 & 61.88 & 230.00 \\
\hline $1990 \mathrm{~s}$ & 1990 & 43324 & 0.12 & 7.41 & 800.00 & 99 & 1.30 & 128.57 & 600.00 \\
\hline $2000 \mathrm{~s}$ & 2000 & 43201 & 0.20 & 26.76 & 3961.96 & 314 & 1.81 & 348.32 & 3410.68 \\
\hline $2010 \mathrm{~s}$ & 2010 & 42367 & 0.68 & 25.27 & 454.21 & 55 & 3.25 & 146.05 & 406.85 \\
\hline Mean & & & 0.14 & 5.41 & 520.71 & & 0.81 & 62.71 & 415.14 \\
\hline
\end{tabular}

\section{Empirical strategy}

Skyscrapers represent an extreme case of intense land use. The services such buildings offer are produced using limited amounts of land and vast amounts of capital. Therefore, tall buildings represent an interesting case in point for the study of the substitutability of land and capital. The starting point for most studies of the substitutability of land and capital is a simple concave production function of degree one for building services $(H)$ with two inputs, land $(L)$ and capital $(K)$. Depending on the mix of land and capital, the nature of the produced building services will differ, e.g., from single-family homes with large exterior spaces to upscale apartment towers with sophisticated designs and materials. The production function defines combinations of land and capital that result in the production of building services that are considered quality-equivalent. Normalizing the price of capital to unity, zero profits imply that $p H=K+r L$, where $p$ is the unit price of building services and $r$ is land rent per unit. By definition, the elasticity of substitution between land and capital is:

$$
\sigma=\frac{d \ln \left(\frac{K}{L}\right)}{d \ln \left(\frac{\partial H}{\frac{\partial L}{\partial H}}\right)}
$$

The early empirical literature is summarized in McDonald (1981). Most studies assume a constant elasticity of substitution (CES) production function. The most general form of the CES production function is obtained by substituting the first-order conditions for profit maximization into equation (1). 
The result implies a simple linear relationship between the log of the capital to land ratio and the $\log$ of land rent.

$$
\ln \left(\frac{K}{L}\right)=q+\sigma \ln (r)
$$

where $q$ is a constant. As long as $\sigma>0$, equation (1) implies that as land prices increase, developers substitute away from land and use relatively more capital. The special case of $\sigma=1$ implies that developers substitute between factors maintaining constant factor shares. Any value in between $(0<$ $\sigma<1$ ) implies that the cost share of land in the production of building services increases as the price increases, i.e. the effect of a higher land price on the cost of land dominates the effect of a lower quantity of land consumed. Such limited substitutability may arise for a variety of reasons. Residents may value access to private or communal exterior spaces. Firms may value ground-floor accessibility to bring in inputs. Facilities such as car parks may be land intensive and costly to move to higher floors.

Estimation of equation (1) requires a measure of the building-specific capital to land ratio and a measure of land price. Empirically, the capital stock embedded in the structure of developed properties is notoriously difficult to observe because it is usually traded together with the underlying plot of land, making the values of structure and land hard to separate. For tall buildings, it is plausible to relate building capital to building height via a construction cost function that is convex in height $S=F / T$, where $F$ is the total floor space and $T$ is the building footprint. A convex construction cost function implies that the average construction cost per unit of floor space $F$ increases in height at an increasing rate because taller buildings require more sophisticated structural engineering, expensive building materials, and additional facilities such as elevators:

$$
K=c S^{\theta} F
$$

where $c$ is a scalar capturing the baseline floor space construction cost and $\theta$ is the elasticity of construction cost with respect to height. Another concern related to the estimation of equation (1) is that the size of the footprint $T$ of a tall structure does not necessarily correspond to the size of the land parcel, L. For every unit of building footprint of a tall building, the developer needs to purchase additional land to provide parking space, driveways, amenities such as green spaces and playgrounds or simply some clearance space to other buildings. Because taller buildings host more employees and residents, such "extra space" may depend on the height of the tall structure. While the city of Chicago has not imposed explicit restrictions on building heights since the 1920s, there are floor area ratio (FAR) regulations, which imply that developers face a trade-off between height and a larger fraction 
of extra space. For "planned developments", developers can negotiate FAR bonuses if they provide additional public spaces. If the regulation is binding, it will lead to a (more) positive extra space elasticity with respect to height $\lambda$, which relates the parcel size $L$ to the building footprint $T$ via the building height $S$.

$$
L=l S^{\lambda} T
$$

Substituting (3) and (4) into (2) gives:

$$
\ln (S)=q+\frac{\sigma}{1+\theta-\lambda} \ln (r)
$$

Equation (5) defines the elasticity of height with respect to land price as $\ln (S) / \ln (r)=\beta=$ $\sigma /(1+\theta-\lambda)$. The height elasticity is a composite parameter that reflects the non-construction cost related substitutability of land and capital in the production of building services $(\sigma)$, the relative cost of building taller $(\theta)$, and the extent to which taller buildings require larger amounts of extra space $(\lambda)$. The height elasticity is positive for plausible parameter values $(\sigma>0, \theta \geq 0, \lambda<1+\theta)$. The straightforward implication is that more expensive locations will have taller buildings. The height elasticity is, thus, a critical determinant of the vertical structure of cities. If the height elasticity varies across buildings accommodating different uses, it will also be a determinant of horizontal land use patterns. Those uses associated with a greater height elasticity will be more efficiently hosted in taller buildings in denser and more expensive parts of a city.

It is worth noting that the relationship between the two endogenous variables heights $(S)$ and land price $(r)$ is independent of demand-side factors. The intuition is that the land price is a residual in the profit function. Developers build up to the height where the marginal cost of constructing an extra floor equates to the marginal revenue. Any factors that increase the floor space price will increase the profitable building height. Taller buildings generate more profits per land unit. Through the collective bidding process that equalizes profits, these profits eventually capitalize into the land price. In equilibrium, locational factors such as amenities and agglomeration affect both heights and land prices, but it is the elasticity of substitution between land and capital, the shape of the construction cost function, and the extent to which extra space depends on building height that determine the functional relationship between height and land price. A positive height premium in the floor space prices (Liu et al., 2015) also increases the profitable building height, leading to taller buildings, but does not affect the height elasticity. In the appendix (section 3), we formally derive these predictions from a simple model of profit-maximizing development of tall buildings for the special case of $\sigma=1$. 
One important implication is that demand-side factors such as amenities and agglomeration, which affect heights and land prices through floor space prices, must not be controlled for when estimating the height elasticity using a reduced-form empirical specification:

$$
\ln \left(S_{i t}\right)=\alpha_{t}+\beta_{i t} \ln \left(r_{i t}\right)+\varepsilon_{i t}
$$

where $i$ is an index for location, $t$ indicates the building's construction date, $\alpha_{t}$ is a decadal construction cost fixed effect, and $\varepsilon_{i t}$ is a random error term. Since our data set is nearly comprehensive regarding the recorded heights of tall building constructions as well as the spatiotemporal distribution of land prices, we are able to estimate height elasticities that are specific to different locations at different points in time. However, the elasticity of substitution $\sigma=(1+\theta-\lambda) \beta$ will not be determined unless estimates of $\theta$ and $\lambda$ are available.

To infer the elasticity of substitution from our height elasticity estimates we make use of somewhat less complete data to estimate $\theta$ and $\lambda$. To obtain estimates of $\theta$, we estimate a variant of equation (3):

$$
\ln \left(\frac{K}{F}\right)_{\mathrm{it}}=\alpha_{t}+\theta \ln \left(S_{i t}\right)+\varepsilon_{i t},
$$

Substituting $T=F / S$ equation (4) can be solved for $\frac{F}{L}=\frac{1}{l} S^{1-\lambda}$, which leads to the following empirical specification:

$$
\ln \left(\frac{F}{L}\right)_{\mathrm{it}}=\alpha_{t}+\gamma \ln \left(S_{i t}\right)+\varepsilon_{i t},
$$

where $\lambda=1-\gamma$. While $\theta$ and $\lambda$ are necessary to infer the elasticity of substitution from the height elasticity, they are also interesting in their own right as they determine the verticality of cities and have remained understudied in empirical research. While classic papers have estimated the elasticity of substitution based on equation (2) and a measure of capital that uses the price of land as an ingredient (McDonald, 1981), the price of land does not appear on both sides of any of our estimation equations. Measurement error in land price, therefore, is less likely to cause attenuation bias in our estimates.

\section{Empirical analysis}

\subsection{Height and land price gradients}

As is evident from Figure 1, the geography of tall buildings in Chicago allows for a stylized representation of urban form as a function of the vertical (latitude) geographic coordinate. Figure 4 compares building heights in 2014 to corresponding land prices for 1990. The heights in the figure provide a 
stylized representation of the Chicago skyline as seen from Lake Michigan. Two patterns emerge from Figure 4. First, the degree of correlation between building heights and land prices is striking within the CBD where the highest land prices and building heights are observed. Second, outside the densest central area we frequently observe relatively tall buildings of about 100 meters' height, despite relatively low land prices, which suggests that the cost of building taller rapidly increases beyond this threshold.

\section{Fig. 4. Building height and land prices}

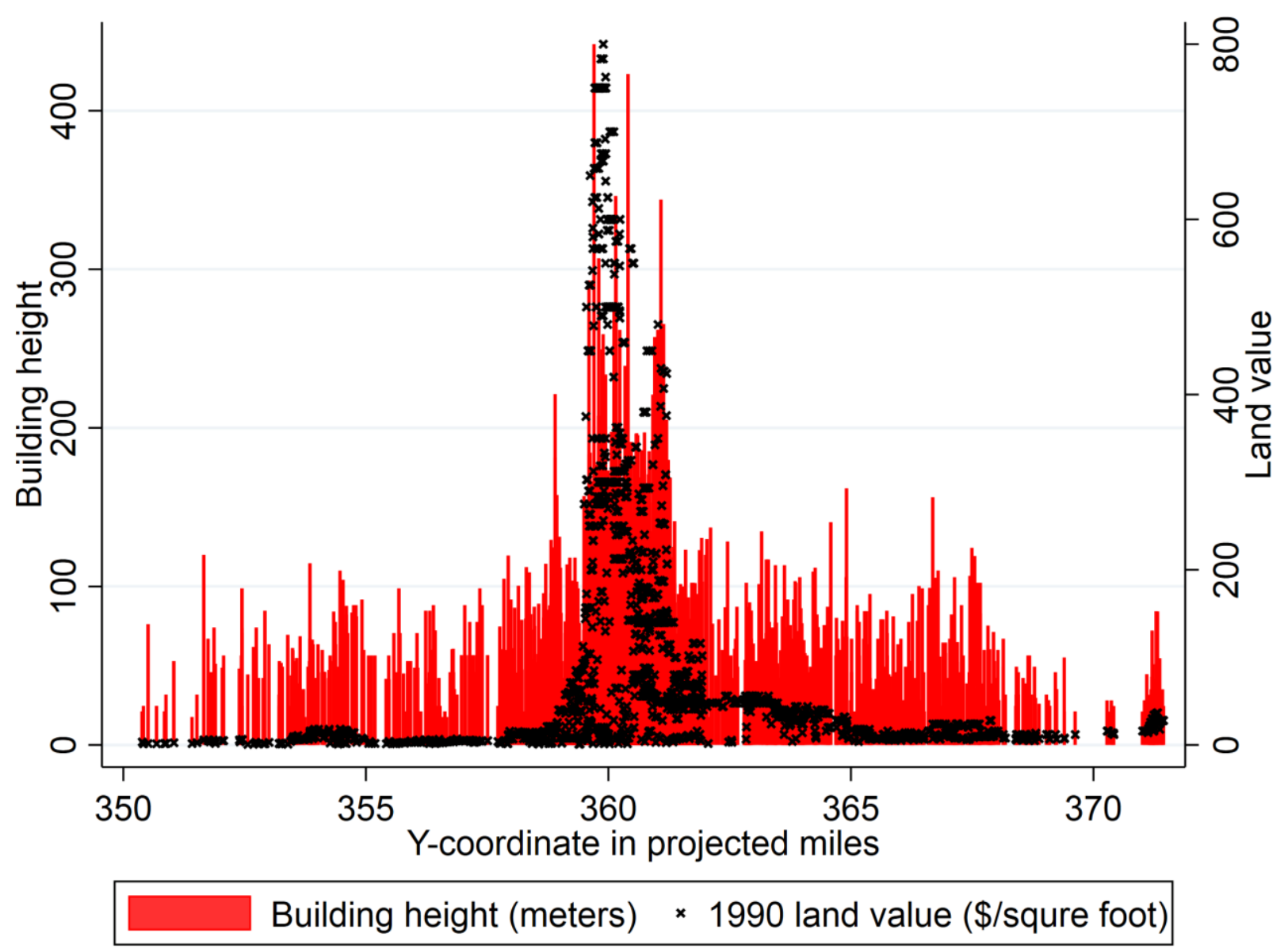

Notes: The building heights in 2014 are from Emporis.com. The 1990 land values are from Olcott's blue books. The $\mathrm{y}$-coordinate is the vertical Cartesian coordinate in the State Plane Coordinate System (Illinois East).

In Figure 5 we summarize the spatiotemporal pattern of land prices and heights of newly constructed tall buildings. The left heat map shows the mean log land value normalized to have a mean of zero within cohorts. The grid cells are defined for each combination of decade and one-mile distance from the CBD. The right heat map similarly shows the mean height of newly constructed buildings within the same grid cells. We identify the CBD as the nucleus of log-linear height and land price gradients 
in auxiliary nonlinear least squares (NLS) estimations, which are discussed in more detail in the appendix (section 4.1). In general, our estimates suggest that the center of gravity of the city has changed very little over time and is located close to the intersection of Washington Street and State Street, which we choose as the CBD point for all years. ${ }^{12}$

The two heat maps are reflective of some of the major urban phenomena of the $20^{\text {th }}$ century, suburbanization and gentrification. Land prices were highest within the CBD at any time. Starting in the 1920s a tendency toward decentralization of high land prices is evident, which is in line with reductions in transport cost due to the completion of the elevated train lines and the rise of the automobile. The trend is reversed from the 1990s onwards. A similar height gradient starts emerging in the 1920s when construction technology allowed for increasingly tall residential and commercial buildings. From then on, with the exception of the 1940s, the CBD is the location of the tallest constructions. At the peak of suburbanization during the 1960s and 1970s, we observe construction of relatively tall buildings at relatively remote locations. Another notable feature is the inverse height gradient in the $19^{\text {th }}$ century, which is largely explained by the majority of tall buildings being technical structures or churches (see also Figure 2).

12 For each decade $t$ we run an auxiliary NLS estimation of the following form: $\log \left(C_{i t}\right)=\gamma_{0 t}+\gamma_{1 t}\left(\left(X_{i t}-\gamma_{t}^{X}\right)^{2}+\left(Y_{i t}-\gamma_{t}^{Y}\right)^{2}\right)^{0.5}+\epsilon_{i t}$, where $C_{i t}$ is either the height of a building $i$ constructed in a decade $t$ or the price of the underlying plot of land, $X_{i t}$ and $Y_{i t}$ are cartesian coordinates of buildings, and $\gamma_{t}^{X}$ and $\gamma_{t}^{Y}$ are the coordinates of the CBD to be estimated along with the other parameters $\gamma_{0 t}$ and $\gamma_{1 t}$. The traditional center of Chicago, at the intersection of State and Madison Street, is only one block south of the site identified using this procedure. 
Fig. 5. Land price and height gradients: Spatiotemporal heat maps
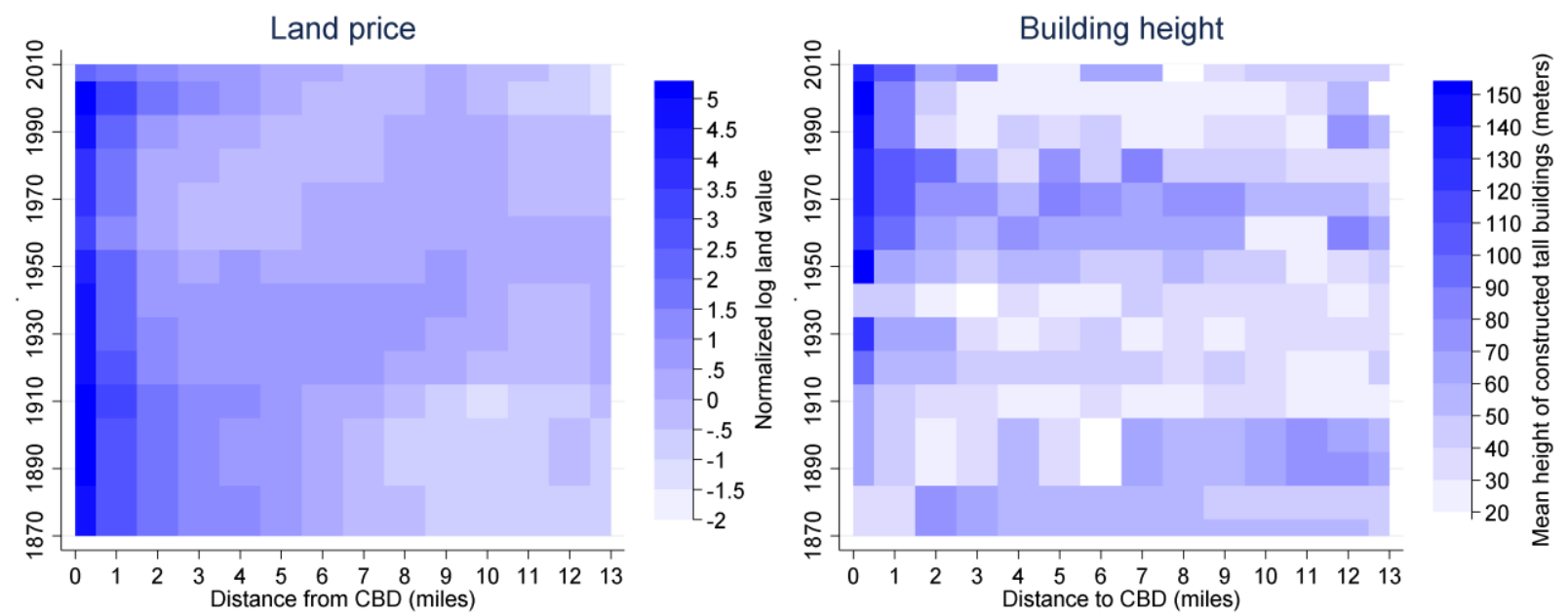

Notes: Heat maps show mean values (using all data) within one-mile distance from the CBD x construction date cohorts (decades). Log land values are normalized to have a zero mean within a cohort. Tall buildings are defined as buildings with at least five floors. Building heights are from Emporis.com. Land values are based on Hoyt and Olcott (1870s-1900s), Olcott (1910s-1990s) and vacant land transactions and Olcott (2000s-2010s).

In Table 3 we provide parametric estimates of land price and height gradients obtained from separate regressions of log land prices and log heights against log distance from the $\mathrm{CBD}$ for every construction cohort. We distinguish between the full set of land prices covering the entire city area and the land prices matched to the construction data set. The results are consistent with Figure 5, reflecting suburbanization during the mid- $20^{\text {th }}$ century and subsequent gentrification. Notably, the price gradient is generally steeper within the sample of new construction than for the city as a whole, reflecting that land prices decline particularly quickly within the downtown section, as evident from Figure 4. Importantly, we find that that the land price elasticity is significantly larger than the height elasticity. This result points to an elasticity of height with respect to land price of less than one. 
Tab. 3. Land price and height gradients: Parametric estimates

\begin{tabular}{|c|c|c|c|c|c|c|}
\hline \multirow[t]{2}{*}{$\begin{array}{l}\text { Construction } \\
\text { cohort }\end{array}$} & \multicolumn{2}{|c|}{$\begin{array}{l}\text { Land price: All grid } \\
\text { cells }\end{array}$} & \multicolumn{2}{|c|}{$\begin{array}{l}\text { Land price: New construc- } \\
\text { tions }\end{array}$} & \multicolumn{2}{|c|}{$\begin{array}{l}\text { Height of new construc- } \\
\text { tions }\end{array}$} \\
\hline & Elasticity & R2 & Elasticity & R2 & Elasticity & R2 \\
\hline $1870 \mathrm{~s} \&$ 1880s & -1.63 & 0.72 & -4.89 & 0.78 & 0.46 & 0.05 \\
\hline $1890 \mathrm{~s} \& 1900 \mathrm{~s}$ & $-1.39^{\text {*** }}$ & 0.49 & $-3.33^{\text {*a* }}$ & 0.70 & $-0.33^{\text {*a* }}$ & 0.13 \\
\hline $1910 \mathrm{~s}$ & $-1.63^{\text {*** }}$ & 0.43 & $-2.18^{\text {*小a }}$ & 0.63 & $-0.46^{\text {*a* }}$ & 0.36 \\
\hline $1920 \mathrm{~s}$ & $-0.97^{\text {*a* }}$ & 0.23 & $-1.00^{* \pi}$ & 0.52 & $-0.36^{\pi * \pi}$ & 0.33 \\
\hline $1930 \mathrm{~s}$ & $-0.85^{n-\pi}$ & 0.21 & $-0.91^{\ldots \ldots \pi}$ & 0.45 & -0.56 & 0.50 \\
\hline $1940 \mathrm{~s}$ & $-0.75^{\text {*** }}$ & 0.20 & 0.20 & 0.02 & -0.06 & 0.01 \\
\hline $1950 \mathrm{~s}$ & $-0.56^{\text {*** }}$ & 0.15 & $-0.84^{\text {*小a }}$ & 0.10 & $-0.37^{\text {*א* }}$ & 0.25 \\
\hline $1960 \mathrm{~s}$ & $-0.19^{\text {*小* }}$ & 0.03 & $-0.94^{\text {*小水 }}$ & 0.20 & $-0.29^{* * *}$ & 0.18 \\
\hline $1970 \mathrm{~s}$ & $-0.32^{\text {**a }}$ & 0.08 & $-1.48^{\text {*小a }}$ & 0.48 & $-0.37^{\text {*小a }}$ & 0.18 \\
\hline $1980 \mathrm{~s}$ & $-0.42^{\text {*** }}$ & 0.08 & $-1.80^{\text {* }}$ & 0.61 & $-0.56^{\text {*** }}$ & 0.29 \\
\hline $1990 \mathrm{~s}$ & $-0.69^{\text {*** }}$ & 0.17 & $-2.05^{\text {*** }}$ & 0.73 & $-0.70^{\text {*** }}$ & 0.36 \\
\hline $2000 \mathrm{~s}$ & $-1.42^{\text {**a }}$ & 0.43 & $-1.99^{\text {** }}$ & 0.68 & $-0.75^{\text {*א* }}$ & 0.40 \\
\hline $2010 \mathrm{~s}$ & $-1.03^{\text {*a* }}$ & 0.38 & $-0.83^{\text {*a* }}$ & 0.18 & $-0.78^{\text {*a* }}$ & 0.30 \\
\hline Mean & -0.91 & 0.28 & -1.70 & 0.47 & -0.40 & 0.26 \\
\hline
\end{tabular}

Notes: Tables shows gradient estimates obtained from regressions of log of land price or log of height on log of distance from the CBD. Height data from Emporis.com. Olcott's land values (1913-1990) to which own estimates for 1873 and 1892 (based on Hoyt) and 2000 and 2010 (based on vacant land sales) have been merged. ${ }^{* * *} p<0.01$.

In Figure 6 we turn our attention to two important amenities in Chicago, Lake Michigan and the Chicago River. Lake Michigan offers attractive recreational spaces such as parks and beaches along its shore. Although the river was once heavily polluted and only recently has become a highly desirable amenity, both bodies of water offer attractive views, which tend to add to the value of properties and may create incentives to build taller. As expected, we find that, controlling for time-varying proximity to CBD effects, new buildings are significantly taller and land is significantly more expensive nearer to Lake Michigan and Chicago River. Whereas heights and land prices decline relatively gradually with distance from Lake Michigan, the effects of the Chicago River are more localized. Building heights, on average, increase by about $50 \%$ within a fourth of a mile as one gets closer to the river. A similar but somewhat smaller localized effect is evident for land prices. Such a localized effect is consistent with a view amenity that gets easily obstructed by other buildings within the CBD. The wider effects found for Lake Michigan suggest that the views can be enjoyed over larger distances since the density of tall buildings is lower along the lake, or that Lake Michigan is an amenity that is not enjoyed exclusively through a view. 


\section{Fig. 6. Distance from Lake Michigan and Chicago River effects}
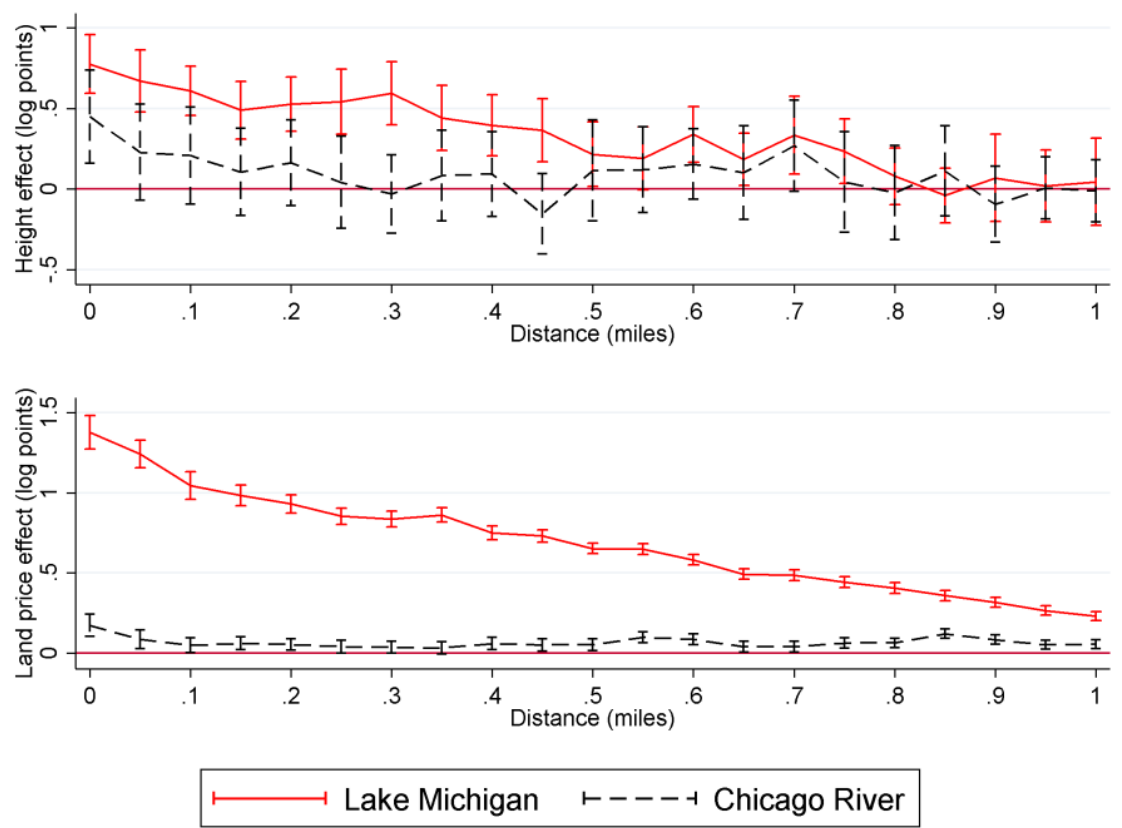

Notes: The figure illustrates results from two regressions of log of height (upper panel) and log of land price (lower panel) on 0.05-mile distance-from-Lake-Michigan bins and 0.05-mile distance-from-Chicago-River bins. We include 21 distance bins defined as follows: 0-0.025 miles, 0.025-0.075 miles, ... 0.975-1.025 miles. In each regression, we include two dummy variables indicating a $0-2$ mile buffer, so that the point estimates displayed give the difference within a distance bin and the respective 1.025-2 mile area in the buffer. The regressions include controls for a full set of quarter mile distance from the CBD bin x decade effects. Standard errors are clustered on quarter mile distance from the CBD bin x decade effects. Solid lines connect the distance bin point estimates. Vertical error bars indicate the $95 \%$ confidence intervals.

In Table 4 we present estimates of the height gradient obtained by regressing the log of building height against a set of covariates using the entire sample of new constructions. Besides the CBD, which is the primary concentration of economic activity and urban amenities, we also consider Lake Michigan and the Chicago River as additional important amenities. Informed by Figure 6, we choose to approximate the amenity value of Lake Michigan in terms of a gradual distance measure while the more localized effects of the Chicago River are captured by a variable indicating that the building is within a tenth of a mile of the river. We control for the construction year using a trend variable that is zero in 2000 .

According to our baseline model (column 1) the elasticity of height with respect to distance from the CBD is $-35 \%$, which is close to the mean across construction cohorts of $-40 \%$ reported in Table 3 . The effect of Lake Michigan is even larger at $-44 \%$,. Being within a tenth of a mile of the Chicago River is estimated to increase heights by $39.2 \%$. On average, building heights increased by $4 \%$ every decade. In column (2) we allow for an interaction between the trend variable and the other covariates. In 2000, the predicted CBD distance elasticity of $42.3 \%$ is about twice as large as in $190042.3 \%$ - 
$2 \% \times 100=22.3 \%$ ). Similarly, the effects of proximity to Lake Michigan and Chicago River have increased over time, pointing to an increase in amenity value. In columns (3) and (4) we replicate model (2) separately for commercial and residential buildings. The parameter estimates are within the same range, but generally larger for commercial buildings.

Tab. 4. Pooled gradient estimates

\begin{tabular}{|c|c|c|c|c|c|c|}
\hline & (1) & (2) & (3) & (4) & $(5)$ & (6) \\
\hline & $\begin{array}{l}\text { Log } \\
\text { building } \\
\text { height }\end{array}$ & $\begin{array}{l}\text { Log } \\
\text { building } \\
\text { height }\end{array}$ & $\begin{array}{l}\text { Log } \\
\text { building } \\
\text { height }\end{array}$ & $\begin{array}{l}\text { Log } \\
\text { building } \\
\text { height }\end{array}$ & $\begin{array}{l}\text { Log land } \\
\text { price }\end{array}$ & $\begin{array}{l}\text { Log land } \\
\text { price }\end{array}$ \\
\hline Log distance to CBD & -0.350 & -0.423 & -0.487 & -0.375 & -0.839 & -0.541 \\
\hline Log distance to Lake Mich- & $\begin{array}{l}(0.018) \\
-0.436\end{array}$ & $\begin{array}{l}(0.035) \\
-0.521^{* \pi \times \pi}\end{array}$ & $\begin{array}{l}(0.131) \\
-0.606\end{array}$ & $\begin{array}{l}(0.040) \\
-0.601^{* \pi \times \pi}\end{array}$ & $\begin{array}{l}(0.003) \\
-0.458\end{array}$ & $\begin{array}{l}(0.005) \\
-0.175^{\text {* }}\end{array}$ \\
\hline igan & $(0.033)$ & $(0.049)$ & $(0.225)$ & $(0.057)$ & $(0.002)$ & $(0.004)$ \\
\hline $\begin{array}{l}\text { Chicago River within } 0.1 \\
\text { mile (dummy) }\end{array}$ & $\begin{array}{l}0.311^{\text {ra }} \\
(0.050)\end{array}$ & $\begin{array}{l}0.366^{\text {rat }} \\
(0.069)\end{array}$ & $\begin{array}{l}0.285^{\text {*a }} \\
(0.112)\end{array}$ & $\begin{array}{l}0.266^{\text {Na* }} \\
(0.085)\end{array}$ & $\begin{array}{l}0.028^{\text {an }} \\
(0.010)\end{array}$ & $\begin{array}{l}0.089^{*}= \\
(0.022)\end{array}$ \\
\hline Year -2000 & $0.004^{* \pi * \pi}$ & $0.008^{* 2 \pi}$ & $0.011^{\text {尔自 }}$ & $0.008^{\text {尔 }}$ & $0.040^{\text {米尔 }}$ & $0.023^{* N_{*}}$ \\
\hline $\begin{array}{l}\text { Log distance to CBD } x \\
\text { (year - 2000) }\end{array}$ & & $-0.002^{* \pi * \pi}$ & 0.000 & $-0.002^{* \pi \kappa}$ & & 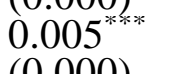 \\
\hline $\begin{array}{l}\text { Log distance to Lake Mich- } \\
\text { igan x (vear - 2000) }\end{array}$ & & $-0.004^{2 \ldots \ldots}$ & -0.002 & $-0.005^{5}$ & & $0.005^{-1 \pi n}$ \\
\hline Chicago River x (year - & & $(0.001)$ & 0.003 & $\begin{array}{l}(0.002) \\
0.003\end{array}$ & & $0.001^{\text {*小a }}$ \\
\hline 2000$)$ & & & & & & \\
\hline Constant & $\begin{array}{l}4.769^{\text {* }} \\
(0.038)\end{array}$ & $\begin{array}{l}4.885^{\text {(0.046) }} \\
(0.046\end{array}$ & $\begin{array}{l}5.380^{2} \\
(0.140)\end{array}$ & $\begin{array}{l}4.874^{\text {(0.0. }} \\
(0.054)\end{array}$ & $\begin{array}{l}4.065^{\text {к小к }} \\
(0.006)\end{array}$ & $\begin{array}{l}3.071^{\text {(0.012) }} \\
(0.012)\end{array}$ \\
\hline f observation & Buildings & Buildings & Buildings & Buildings & Grid cells & Grid cells \\
\hline Land use & All & All & $\begin{array}{l}\text { Commer- } \\
\text { cial }\end{array}$ & $\begin{array}{l}\text { Residen- } \\
\text { tial }\end{array}$ & All & All \\
\hline $\begin{array}{l}\text { Observations } \\
R^{2}\end{array}$ & $\begin{array}{l}1,737 \\
.325\end{array}$ & $\begin{array}{l}1,737 \\
.341\end{array}$ & $\begin{array}{l}327 \\
.492\end{array}$ & $\begin{array}{l}1,109 \\
.343\end{array}$ & $\begin{array}{l}625,316 \\
.791\end{array}$ & $\begin{array}{l}625,316 \\
.801\end{array}$ \\
\hline
\end{tabular}

Notes: The data used in columns (1-4) are a cross-section of building constructions. The data used in columns (5) and (6) represent a panel where grid cells define the spatial dimension and cohorts (see Table 2) are the time dimension. Grid cells are defined as 330 × 330 foot tracts that closely follow the Chicago grid street structure. Robust standard errors in parentheses. ${ }^{*} p<0.1,{ }^{* *} p<0.05,{ }^{* * *} p<0.01$

In columns (5) and (6), we replicate the models from columns (1) and (2) using the log of land price as the dependent variable. The CBD effects are generally in line with the estimates provided in Table 3. The time interaction suggests that the general tendency of the past 140 years has been decentralization, but the linear time interaction does not capture the resurgence of the CBD since the late $20^{\text {th }}$ century. Unlike the results for heights, we find that the effect of Lake Michigan on the land price gradient has decreased over time. In line with our estimated height gradients, the amenity value of the Chicago River has increased. In fact, the river has turned from a disamenity, which depreciated land price by about $0.89-100 \times 0.01 \approx-1.1 \%$, into an amenity, which increases land prices by about $9 \%$ from 1900 to 2000. These capitalization effects presumably reflect a number of improvements made over 
the course of the $20^{\text {th }}$ century to transform the "stinking river" as it was called at the end of the $19^{\text {th }}$ century into the amenity it currently represents. ${ }^{13}$

\subsection{The elasticity of height with respect to land price}

A central prediction of supply side urban models is that as land prices increase, developers should increase the density of land use, i.e., build taller. Figure 7 plots building heights against the land prices at the beginning of the decade when a building was completed. To account for land price inflation and changes in construction technology, log land prices and log heights are normalized to have means of zero within construction cohorts (decades). Figure 7 suggests a positive elasticity of height with respect to land price across all construction cohorts. As suggested by Table 3, the elasticity's value is less than one, which is consistent with the expected increasing marginal cost of building taller. Figure 7 is also reflective of the typical urban land use pattern, with tall commercial buildings occupying the most central and expensive spots in the city.

Table 5 presents parametric estimates of the elasticity of height with respect to land price following specification (6). All models feature cohort specific intercepts so that the elasticity is identified by variation within cohorts. Our estimates suggest an average elasticity of height with respect to land price of $24.6 \%$ (column 1).

One concern with this estimate is that assessors may have been influenced by the announcement of tall buildings and assigned high land values not because of a fundamental locational advantage but because they knew a tall building was under construction. Another concern is that unobserved supply-side factors such as soil conditions may influence building heights and land prices. As an example, solid bedrock reduces the cost of constructing tall buildings (Barr et al., 2010), potentially leading to taller buildings and land prices. Consequently, if bedrock quality varies within the city area, the elasticity of height with respect to land price will be upward biased compared to the ceteris paribus scenario. In the case of Chicago, it is plausible to abstract from bedrock since the whole city is built on sandy soil. Indeed, it is the lack of bedrock near to the surface in Chicago that is often reported to have spurred architectural innovations such as the steel frame (Bentley and Masengarb, 2015; United States

13 The reversal of the flow of the Chicago River in 1900, which was named a "Civil Engineering Monument of the Millennium" by the American Society of Civil Engineers (ASCE News, 2001), represented a milestone that relieved the river from sewage and pollution. During the 1990s the river underwent extensive cleaning from garbage as a part of the beautification program by Chicago Mayor Richard M. Daley. 
Department of Agriculture, 2012).${ }^{14}$ Still, to address both concerns that may lead to an upward bias of the height elasticity estimate, we use distance from the CBD, distance from Lake Michigan, and a dummy for being within a tenth of a mile of the Chicago River as instruments for land prices. These variables are relevant predictors of land prices as discussed in section 4.1. Demand-side variables are excludable instruments on theoretical grounds (see discussion in section 3). Thus, we make the identifying assumption that the instruments are uncorrelated with supply-side factors (e.g. subsoil geology) and only affect land prices via an amenity demand-side channel. The IV height elasticity point estimate in column (2) is slightly larger than in the OLS estimation, which is not consistent with the suspected direction of the bias resulting from the above-mentioned estimation concerns.

14 If solid bedrock significantly reduces the cost of building tall, cities with a generally more favorable subsoil geology should have a higher height elasticity. 
Fig. 7. Elasticity of height with respect to land price: Pooled correlations

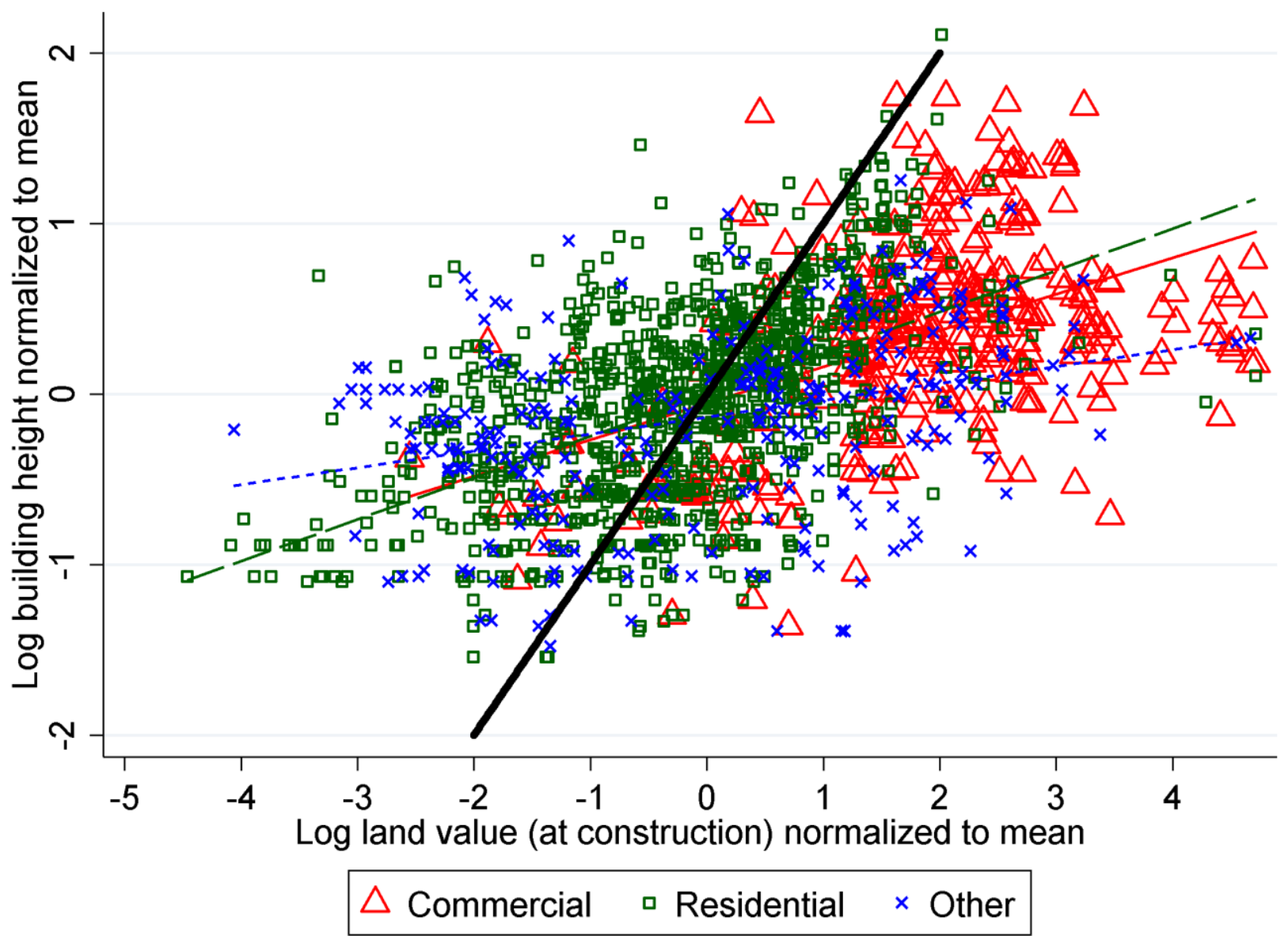

Notes: Log heights and log land values are normalized to zero means within decades. The thin solid (long-dashed) [short-dashed] line is the linear fit for commercial (residential) [other] buildings. The thick solid line is the 45degree line.

Given ongoing innovations in construction technology, we expect the construction cost function to become less convex over time, which would be reflected in an increasing elasticity of height with respect to land price. Thus, in column (3) we allow for an interaction with a linear year trend, set to zero for 2000. The estimates imply an elasticity of 30.5\% in 2000 and a doubling over the course of the century (the implied elasticity in 1900 is $30.5 \%-100 \times 1.6 \%=14.4 \%$ ). 
Tab. 5. Elasticity of density with respect to land price: Parametric estimates

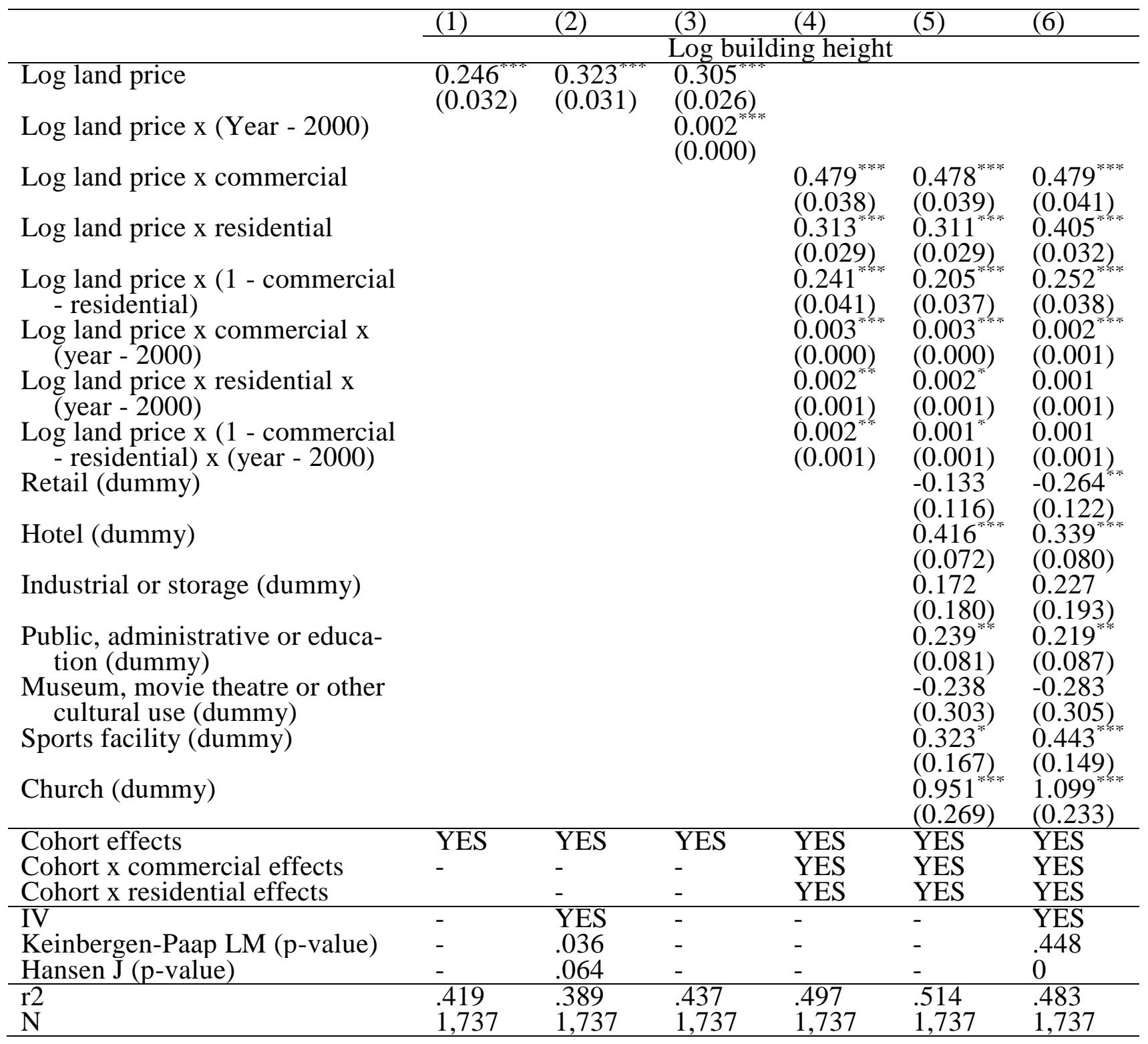

Notes: Standard errors (in parentheses) are clustered by construction date cohorts (decades). IV models in (2) and (6) are estimated using 2SLS. Instruments for log land price in model (2) include log distance from the CBD, log distance from Lake Michigan, and a dummy variable for being within a tenth of a mile of Chicago River. In model (6), interactions of the same variables and land use indicators as well as time trends are instruments for the interactions of log land prices and land use indicators as well as time trends. To compute the over-identification statistics, exogenous regressors are partialled out using the Frisch-Waugh-Lovell Theorem (Giles, 1984). ${ }^{*} p<0.1,{ }^{* *} p<0.05,{ }^{* * *} p<0.01$.

In column (4), we allow the elasticity and its time trend to differ across commercial, residential, and other buildings. The elasticity is largest and increases fastest over time for commercial buildings, and is particularly small for non-commercial, non-residential buildings. In 2000, the estimated elasticity for commercial buildings was $47.9 \%$, as opposed to $17.9 \%$ in 1900 . Likewise, the estimated elasticity for residential buildings was $32 \%$ in 2000 , compared with $12 \%$ in 1900 . For the remaining buildings, the elasticity is around $20 \%$ in 2000 and, again, about half that size in 1900. In column (5), we add a 
number of controls for non-commercial and non-residential land uses. The most impressive finding is that churches tend to be almost $2.6(\exp (0.951)=2.58)$ times as tall as would be predicted by the underlying land price for the category of non-commercial and non-residential buildings. In column (6), we use the instruments from column (2) and the interactions with land use and time trend as instruments for the current land price and the respective interactions. The coefficients of interest increase moderately as in column (2). Since this pattern is not in line with the potential reverse-causality and omitted-variable problems discussed above, we prefer the OLS estimates in column (5). As shown in appendix section 4.2 , the results are robust to the use of alternative instruments.

The models reported in Table 5 are relatively restrictive in that they assume a construction technology that changes at a constant rate over time and an elasticity of height with respect to land price that is otherwise constant within the three land use categories. It is possible however that the time trend follows a non-linear pattern and that the elasticity varies across locations, e.g., because it is more expensive to build a tall structure within a dense CBD. To allow for more flexible variation in the elasticity we estimate LWR versions of model (4) in Table 5. For each construction $\tilde{\imath}$ we run one LWR in which we weight observations using a Gaussian kernel:

$$
w_{i \tilde{\imath}}=\prod_{n} \frac{1}{\kappa_{n} \sqrt{2 \pi}} \exp \left(-\frac{1}{2}\left(\frac{d_{i \tilde{n}}}{\kappa_{n}}\right)^{2}\right)
$$

where $n$ indexes a vector of variables describing the proximity between two constructions $i$ and $\tilde{l}$, including the geographic distance as well as difference between the years of construction, and $\kappa_{n}$ is the bandwidth. ${ }^{15}$ Barr (2013) reports two major changes to the Chicago zoning regime. In 1920, relatively tight building height constraints (61 meters) were relaxed to 183 meters (for towers) and then removed altogether in 1923. Building heights in Chicago have not been limited explicitly ever since, but a zoning plan was introduced in 1957 which defines floor area ratio (FAR) limits throughout the city. Because height decisions potentially depend on the zoning legislation, we run the LWR separately for the periods 1870-1919, 1920-1956, and 1957-2014.

In Figure 8 we plot the resulting local elasticity estimates by year and land use. The results are generally consistent with the parametric estimates. The elasticity increases over time and is higher for commercial buildings than other buildings. In keeping with intuition, the commercial and residential height elasticities increase substantially after building height limits were removed in 1920. This is in line with

15 We use the Silverman (1986) rule for the selection of the bandwidth $\kappa_{n}=1.06 \times \sigma_{n} N^{-\frac{1}{5}}$. 
a casual comparison of building heights and height limits before and after 1920, which suggests that the pre-1920 height regulation was binding (see appendix section 4.5). The introduction of the zoning plan in 1957 reduces the height elasticity, which is intuitive since restrictive FAR limits place implicit limits on building heights. We do not find similar temporal discontinuities in height elasticity estimates for other buildings, suggesting that the pre-1920 height limits as well as the post-1957 zoning plan primarily affect commercial and residential building heights. In the absence of major changes to the zoning regime, the positive trend in the height elasticity after 1957 is likely attributable to improvements in construction technology.

In the appendix, we expand on the analysis of the height effects of the 1957 zoning plan by correlating the LWR-height-elasticity estimates with the legal FAR limits defined for the zoning districts in which constructions are located (section 4.5). We find that after controlling for building use and location (distance from the CBD, Lake Michigan, and the Chicago River) legal FAR limits have a limited effect on the height elasticity. To the extent that the regulation is binding, the effects on height appear to be roughly comparable across zoning districts with different FAR limits. We also show that the LWR height elasticity estimates do not appear to be correlated with other characteristics such as distance from the CBD, building height, or land price (section 4.3). We also provide an LWR-IV version of Figure 8 that shows similar results (section 4.4). In line with the parametric IV models in Table 5, the most notable difference is that the residential height elasticity estimates are somewhat larger.

Finally, we note that in appendix section 4.8 we provide a complementary analysis of the elasticity of the FAR (an imperfect proxy for height) with respect to land price for a nearly comprehensive set of 250 thousand small residential properties in Chicago. We find that the floor area ratio elasticity in the denser and more expensive areas is similar to the height elasticity estimated for tall residential buildings reported here. 
Fig. 8. Elasticity of height with respect to land price: LWR estimates

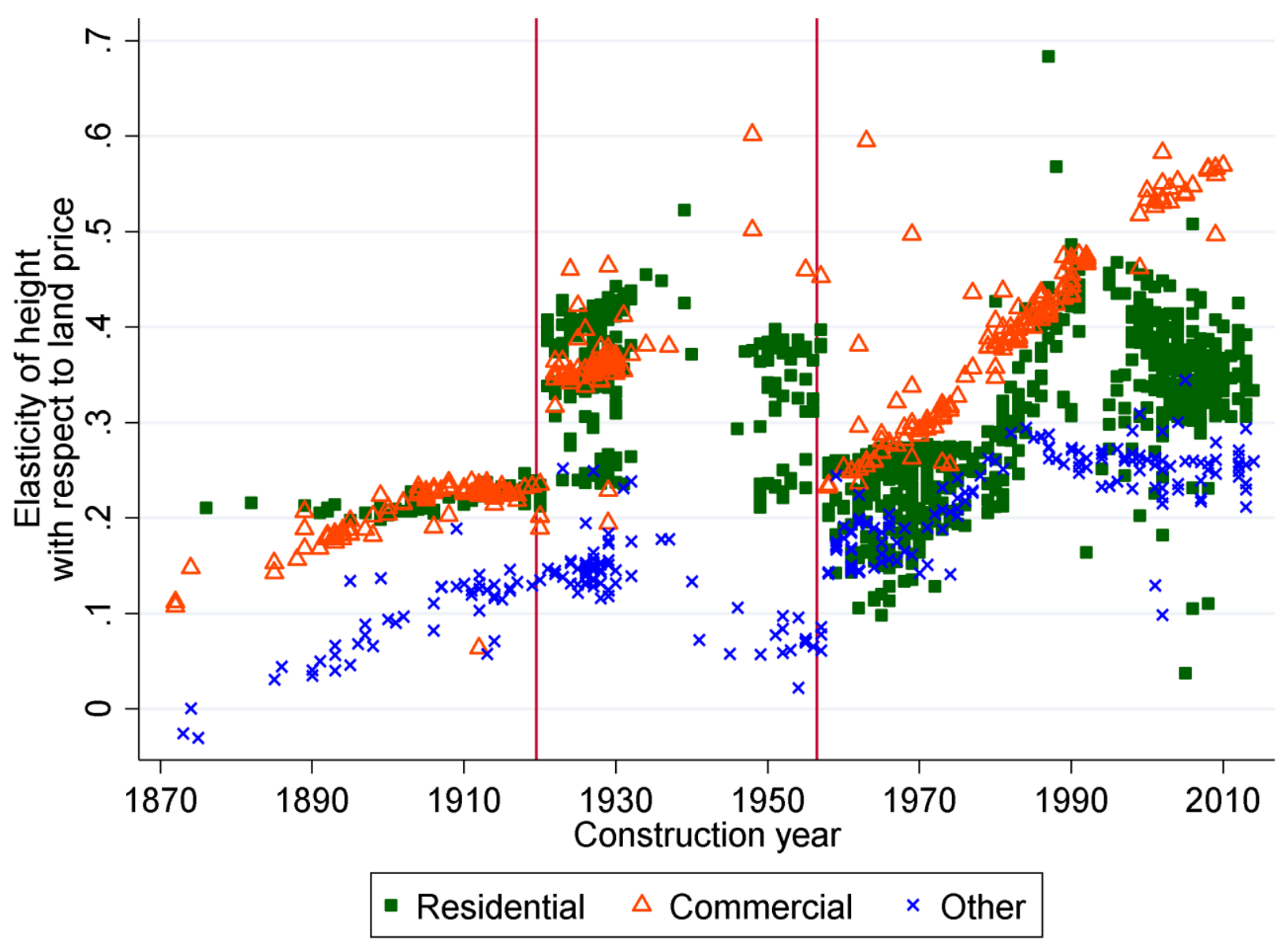

Notes: Each icon represents an LWR estimate of the elasticity of height with respect to land price for a given building $\tilde{\imath}$ built in year $\tilde{t}$. A small number of outliers is excluded to improve readability. The regression model is the same as in Table 5, column (4), except that the model is estimated separately for residential, commercial, and other buildings. Observations are weighted using Gaussian Kernel weights based on the geographic distance from $\tilde{\imath}$ and the time distance from $\tilde{t}$. The bandwidth is selected according to the Silverman (1986) rule. LWR are run separately for the periods 1870-1919, 1920-1956, and 1957-2014. An LWR-IV version based on the model reported in Table 5, column (6) is in the appendix.

\subsection{The elasticity of construction cost with respect to height}

As discussed in section 3, our height elasticity estimates jointly identify the elasticity of substitution, the construction cost elasticity, and the extra space elasticity. To separate the contributions to the height elasticity we require an estimate of the cost elasticity and the extra space elasticity.

While in the engineering literature it is widely acknowledged that construction costs increase in height, there are surprisingly few explicit quantitative analyses of this relationship (Tan, 1999). Therefore, we use the Emporis data to analyze the degree to which per floor space construction cost increases in height. Unfortunately, the data we require (floor space and construction cost) are only available for a small subset of observations, which is why we cannot restrict the sample to Chicago. Data on usable 
floor space are reported for an even smaller subset of observations than gross floor space and construction costs. To estimate the effect of height on usable floor space costs, we therefore impute values of usable floor space using gross floor space and an estimate of the effect of height on the ratio of usable over gross floor space reported in the appendix (Section 4.6). An interesting result of this auxiliary analysis is a significantly negative height effect on this ratio for tall buildings, but not for small buildings with less than five stories. Moreover, this ratio declines twice as fast in height for residential than for commercial buildings.

Our estimates of the elasticity of usable floor space cost with respect to height are in Table 6. Throughout columns (1-5) we estimate the construction cost elasticity for different building types, building uses, and regional samples. It turns out that the construction cost elasticity depends on the average building height, which is a concern because both the full sample as well as the sample restricted to the US contain buildings that are, on average, smaller than those used in our height regressions. To gain insights into the construction cost elasticity for a mix of tall buildings that resemble the Chicago height profile (see appendix section 4.7 for more information) we use a propensity score matching to reweight the US observations (columns 6-7). To estimate the construction cost elasticity for super tall buildings (90 stories and more), which are scarce in our construction costs sample, we use engineering cost estimates for nine categories provided by Lee et al. (2011) in column (8). To relate to the rule of thumb by which construction costs increase by $2 \%$ per floor (Department of the Environment, 1971), we compute the semi-elasticity of cost with respect to the number of floors (at the mean of the distribution of floors) in each case. ${ }^{16}$

This novel statistical analysis of construction costs of tall buildings reveals that the elasticity of construction cost with respect to height increases from $25 \%$ for small buildings to more than $170 \%$ for super-tall buildings. While the $2 \%$ per-floor semi-elasticity reported in the literature is within the range of our estimates, it is an imperfect approximation because the marginal effect of an extra floor is higher for small buildings and lower for super-tall buildings. Another important insight from our analysis is that the cost of height is higher for residential than for commercial buildings. This result is consistent with a larger loss of usable floor space as building height increases (see appendix section 4.6), and is

16 In doing so we divide the cost elasticity by the mean number of floors in the sample, which implicitly assumes that at a given floor level the cost elasticity is the same for both height and floors. 
reflective of some notable differences in the design of commercial and residential towers. Tall residential buildings typically have a smaller floor plate size (due to the need for more exterior walls), use different materials (e.g., all-concrete due to acoustic reasons), and more complex facades (with balconies and sunrooms), all of which is not advantageous for the construction of very tall buildings (Smith et al., 2014).

Tab. 6. Construction cost elasticity estimates

\begin{tabular}{|c|c|c|c|c|c|c|c|c|}
\hline & (1) & $(2)$ & (3) & $(4)$ & $(5)$ & (6) & $(7)$ & (8) \\
\hline & \multicolumn{8}{|c|}{ Log floor space cost } \\
\hline $\begin{array}{l}\text { Log building } \\
\text { height }\end{array}$ & $\begin{array}{l}0.251^{\text {**** }} \\
(0.006)\end{array}$ & $\begin{array}{c}0.475^{* * * *} \\
(0.032)\end{array}$ & $\begin{array}{c}0.634^{* * * *} \\
(0.040)\end{array}$ & $\begin{array}{c}0.541^{* * * *} \\
(0.034)\end{array}$ & $\begin{array}{c}0.612^{* * * *} \\
(0.034)\end{array}$ & $\begin{array}{l}0.523 \\
(0.036)\end{array}$ & $\begin{array}{l}0.611 \\
(0.041)\end{array}$ & $\begin{array}{l}1.729^{* * * *} \\
(0.050)\end{array}$ \\
\hline Country effects & Yes & Yes & Yes & - & - & - & - & - \\
\hline Decade effects & Yes & Yes & Yes & Yes & Yes & Yes & Yes & - \\
\hline Mean \# floors & 2.5 & 15.9 & 15.6 & 12.3 & 9.2 & 20.600 & 20.100 & 110 \\
\hline Semi-elasticity & 0.099 & 0.030 & 0.041 & 0.044 & 0.067 & 0.025 & 0.030 & 0.016 \\
\hline Data & $\begin{array}{c}\text { Ob- } \\
\text { served }\end{array}$ & $\begin{array}{c}\text { Ob- } \\
\text { served }\end{array}$ & $\begin{array}{c}\text { Ob- } \\
\text { served }\end{array}$ & $\begin{array}{c}\text { Ob- } \\
\text { served }\end{array}$ & $\begin{array}{c}\text { Ob- } \\
\text { served }\end{array}$ & $\begin{array}{l}\text { Ob- } \\
\text { served }\end{array}$ & $\begin{array}{l}\text { Ob- } \\
\text { served }\end{array}$ & Engin. \\
\hline Building use & All & Com. & Res. & Com. & Res. & $\begin{array}{l}\text { Com- } \\
\text { mercial }\end{array}$ & $\begin{array}{l}\text { Resi- } \\
\text { dential }\end{array}$ & Com. \\
\hline Building type & Small & Tall & Tall & Tall & Tall & Tall & Tall & $\begin{array}{l}\text { Super- } \\
\text { tall }\end{array}$ \\
\hline Region & World & World & World & US & US & $\begin{array}{l}\text { Pseudo } \\
\text { Chicago }\end{array}$ & $\begin{array}{l}\text { Pseudo } \\
\text { Chicago }\end{array}$ & - \\
\hline $\mathrm{r} 2$ & 0.109 & 0.492 & 0.614 & 0.620 & 0.451 & 0.730 & 0.522 & 0.997 \\
\hline $\mathrm{N}$ & 32016 & 1219 & 1570 & 818 & 1402 & 818 & 1401 & 9 \\
\hline
\end{tabular}

Notes: Observed data are from Emporis. Engineering estimates (Engin.) are from Lee et al. (2011). Ln Floor space cost is computed using predicted usable floor space values based on the regressions reported in appendix section 4.6. Small buildings have less than five floors. Tall buildings have five or more floors. Super-tall buildings have 90 or more floors. The semi-elasticity is computed by dividing the cost elasticity by the mean number of floors. Pseudo Chicago sample is the US sample, reweighted to resemble the distribution of ln building heights in Chicago (using a propensity score matching, see appendix 3.4). For a small percentage of buildings height is imputed based on floors using an auxiliary regression of height against floors (on average height increases by 3.6 meters per floor). Standard errors are in parentheses. $* \mathrm{p}<0.1, * * \mathrm{p}<0.05, * * *$ $\mathrm{p}<0.01$.

\subsection{The elasticity of extra space with respect to height}

After imputing usable floor space using the procedure described in section 4.6 in the appendix, the Emporis data are more comprehensive with respect to floor space than construction costs. Merging the parcel area from an official parcel map available from the Chicago Data Portal in GIS, we obtain small, but reasonable samples of tall commercial and residential buildings suitable to estimate the excess space elasticity. In Table 7, we report the results of regressions of the log of FAR against the log of building height. The estimated elasticities are less than one, suggesting that the FAR increases less than proportionately in height. Taller buildings, thus, are surrounded by larger areas hosting low-rise facilities or open space; be it because users demand amenities or because regulation enforces their 
provision. In any case, the extra space elasticity at $10 \%$ (residential) to $16 \%$ (commercial) is relatively small, suggesting that if the positive elasticity is driven by FAR regulations, the distortions are limited.

Tab. 7. Extra space elasticity estimates

\begin{tabular}{|c|c|c|c|}
\hline & (1) & (2) & \\
\hline & & Ln floor area - ln parcel area & \\
\hline Ln Building height & 0.844 & $\begin{array}{ll}(0.183) & 0.900\end{array}$ & $(0.022)$ \\
\hline Cohort effects & Yes & Yes & \\
\hline Building type & Commercial & Residential & \\
\hline Lambda & .156 & .1 & \\
\hline Floors & 32 & 24 & \\
\hline $\mathrm{r} 2$ & .26 & .569 & \\
\hline $\mathrm{N}$ & 112 & 100 & \\
\hline
\end{tabular}

Notes: Missing usable floor space imputed from gross floor space using the procedure outlined in appendix section 4.6. Robust standard errors. Standard errors clustered on cohorts in parentheses. Robust standard errors. ${ }^{*} p<0.1{ }^{* *} p$ $<0.05,{ }^{* * *} p<0.01$.

\subsection{The elasticity of substitution between land and capital}

With estimates of the construction cost and extra space elasticities at hand, we now turn our attention to the elasticity of substitution between land and capital. To obtain cost elasticity $(\theta)$ estimates at the mean of the distribution of commercial building heights in Chicago (which differs notably from the sample used in Table 6), we multiply the semi-elasticities reported in Table 6, column (6) by the mean number of floors for post-1950 commercial or residential buildings in Chicago (30). Because the average building heights in the samples used to estimate the extra space elasticity is closer to the ones in the samples used to estimate the height elasticities we do not make similar adjustments to the estimated extra space elasticities.

In Table 8, we report estimates of the implied elasticity of substitution that follows from the estimates reported in sections (4.2-4.4). We find a positive elasticity of substitution that is substantially below unity, a value that has been found to be a reasonable approximation for smaller structures (Ahlfeldt and McMillen, 2014; Ahlfeldt et al., 2015; Combes et al., 2013; Epple et al., 2010). For tall structures, it appears to be more difficult to substitute away from the use of land, which is intuitive given that land is already been used intensely.

Another notable feature is that the elasticity of substitution is larger for commercial than for residential tall buildings. The implied elasticities of substitution for 30 -floor commercial buildings is about $76 \%$. Depending on whether we use the OLS or IV estimates of the elasticity of height with respect to land price, estimates for 20-floor residential tall buildings range from 47.3-60.6\%. The positive difference persists if we ignore the differences in average height of commercial and residential buildings. The moderate difference in the extra space elasticity mitigates the difference in the elasticity of substitution. 
These results suggest that land is a relatively more important input in the production of residential housing services. One way to interpret this result is that little exterior space is required to provide attractive office space, thus, this use is highly amenable to stacking in tall high-rises. In contrast, it is more difficult to maintain a constant level of housing services quality as one substitutes away from land. One explanation is that it is more difficult to compensate residents (than office users) for more limited access to private and communal exterior space by investments into capital such as more sophisticated building materials and interior and exterior design.

Tab. 8. Summary of implied parameter estimates

\begin{tabular}{llllllll}
\hline & & \multicolumn{2}{l}{$\begin{array}{l}\text { Commercial } \\
\text { (30 floors) }\end{array}$} & \multicolumn{2}{l}{$\begin{array}{l}\text { Commercial } \\
\text { (20 floors) }\end{array}$} & \multicolumn{2}{l}{$\begin{array}{l}\text { Residential } \\
\text { (20 floors) }\end{array}$} \\
\hline Elasticity & Parameter & OLS & IV & OLS & IV & OLS & IV \\
\hline Height & $\beta$ & $47.8 \%$ & $47.9 \%$ & $47.8 \%$ & $47.9 \%$ & $31.3 \%$ & $40.1 \%$ \\
& & $(3.8 \%)$ & $(4.1 \%)$ & $(3.8 \%)$ & $(4.1 \%)$ & $(2.9 \%)$ & $(3.2 \%)$ \\
Const. cost & $\theta$ & $75.0 \%$ & $75.0 \%$ & $53.3 \%$ & $53.3 \%$ & $61.1 \%$ & $61.1 \%$ \\
& & $(6.1 \%)^{\mathrm{a}}$ & $(6.1 \%)^{\mathrm{a}}$ & $(3.6 \%)$ & $(3.6 \%)$ & $(4.1 \%)$ & $(4.1 \%)$ \\
Extra space & $\lambda$ & $15.6 \%$ & $15.6 \%$ & $15.6 \%$ & $15.6 \%$ & $10.0 \%$ & $10.0 \%$ \\
& & $(18.3 \%)$ & $(18.3 \%)$ & $18.3 \%)$ & $(18.3 \%)$ & $(2.2 \%)$ & $(2.2 \%)$ \\
Substitution & $\sigma=\beta(1+\theta-\lambda)$ & $76.2 \%$ & $76.4 \%$ & $65.8 \%$ & $66.0 \%$ & $47.3 \%$ & $60.6 \%$ \\
& & $(18.14 \%)^{\mathrm{a}}$ & $(19.14 \%)^{\mathrm{a}}$ & $(17.32 \%)^{\mathrm{a}}$ & $(18.09 \%)^{\mathrm{a}}$ & $(4.42 \%)^{\mathrm{a}}$ & $(5.61 \%)^{\mathrm{a}}$ \\
\hline
\end{tabular}

Notes: OLS height elasticity estimates are from Table 5, column (4). IV estimates are from Table 5, column (6). The commercial construction cost elasticity for 30-floor buildings is computed by multiplying the per-floor semi-elasticities reported in Table 6, column (6) by 30 floors (approximately the median values for post-1950 commercial and residential tall buildings in Chicago). The other construction cost elasticities are from Table 6, columns (6) and (7). Extra space elasticities are from Table 7. ${ }^{\mathrm{a}}$ Standard errors (in parentheses) bootstrapped in 1,000 iterations.

\section{Conclusion}

We use a unique combination of data on tall buildings and land prices in Chicago to gain insights into the determinants of building heights and the spatial segregation of land use. Our results are consistent with standard supply-side urban equilibrium models that rationalize the existence of skylines.

We find a positive and statistically significant elasticity of height with respect to land price throughout our study period, which ranges from 1870 to 2010 . In 2000 , the elasticity was $45 \%$ for commercial buildings and $30 \%$ for residential buildings. Over 100 years, the elasticity approximately doubled, which is in line with significant improvements in construction technology as well as a shift towards a less rigid zoning regime. Cities with a more rigid zoning regime (e.g. with explicit height constraints) are expected to have a lower height elasticity while more favorable subsoil conditions (solid bedrock) should increase the elasticity. We also provide estimates of the elasticity of per floor space construction cost with respect to height, which ranges from $25 \%$ for small buildings to well above unity for supertall buildings and is generally larger for residential than for commercial buildings. Our estimates of 
the elasticity of extra space with respect to height a range from $10 \%$ to $15 \%$. Combining these estimates, we infer estimates of the elasticity of substitution between land and capital of $76 \%$ for commercial and $47 \%$ for residential buildings, which is less than typically found for smaller structures.

More generally, these results suggest that there is a supply-side mechanism that promotes the typical land-use segregation observed within cities. The strong concentrations of economic activity that are typically observed within clusters such as central business districts, sub-centers, or edge cities, are likely not only attributable to strong agglomeration forces, but also to a relatively lower cost of accommodating commercial uses in tall structures that minimize the use of expensive land.

\section{Literature}

Ahlfeldt, Gabriel M., \& McMillen, D. P. (2014). New estimates of the elasticity of substitution between land and capital. Lincoln Institute Working paper.

Ahlfeldt, Gabriel M., Redding, Stephan J., Sturm, Daniel M., \& Wolf, Nikolaus. (2015). The Economics of Density: Evidence from the Berlin Wall. Econometrica, 83(6), 2127-2189.

Ahlfeldt, Gabriel M., \& Wendland, Nicolai. (2011). Fifty years of urban accessibility: The impact of the urban railway network on the land gradient in Berlin 1890-1936. Regional Science and Urban Economics, 41(2), 77-88.

Albouy, David, \& Ehrlich, Gabriel. (2012). Metropolitan Land Values and Housing Productivity. NBER Working Paper 18110.

Alonso, William. (1964). Location and land use. Cambridge, MA: Harvard.

Arnott, Richard J., \& MacKinnon, James G. (1977). Measuring the costs of height restrictions with a general equilibrium model. Regional Science and Urban Economics, 7(4), 359-375.

Arzaghi, Mohammad, \& Henderson, J. Vernon. (2008). Networking off Madison Avenue. The Review of Economic Studies, 75(4), 1011-1038.

ASCE News. (2001). Chicago Wastewater System and Hoover Dam Named Monuments of the Millennium by ASCE. ASCE News October 2001, 26(10), 4.

Barr, Jason. (2010). Skyscrapers and the Skyline: Manhattan, 1895-2004. Real Estate Economics, 38(3), 567-597.

Barr, Jason. (2012). Skyscraper Height. The Journal of Real Estate Finance and Economics, 45(3), 723-753.

Barr, Jason. (2013). Skyscrapers and skylines: New York and Chicago, 1885-2007. Journal of Regional Science, 53(3), 369-391.

Barr, Jason, \& Cohen, Jeffrey P. (2014). The Floor Area Ratio Gradient: New York City, 1890-2009. Regional Science and Urban Economics, 48(0), 110-119.

Barr, Jason, Tassier, Troy, \& Trendafilov, Rossen. (2010). Bedrock Depth and the Formation of the Manhattan Skyline, 1890-1915. Fordham University Department of Economics Discussion Paper.

Bentley, Chris, \& Masengarb, Jennifer. (2015). Building skyscrapers on Chicago's swampy soil. WBEZ91.5. Retrieved

from http://www.wbez.org/series/curiouscity/buildingskyscraperschicagosswampysoil111658

Berry, Brian J. L. (1976). Ghetto Expansion and Single-Family Housing Prices. Journal of Urban Economics, 3(4), 397-423.

Bertaud, Alain, \& Brueckner, Jan K. (2005). Analyzing building-height restrictions: predicted impacts and welfare costs. Regional Science and Urban Economics, 35(2), 109-125.

Brown, Eliot. (2012). Tower Rises, And So Does Its Price Tag. The Wall Street Journal.

Brueckner, Jan K. (1987). The structure of urban equilibria: A unified treatment of the Muth-Mills model. In E. S. Mills (Ed.), Handbook of Regional and Urban Economics (Vol. 11, pp. 821-845). Amsterdam: North-Holland.

Brueckner, Jan K. (2003). Strategic Interaction Among Governments: An Overview of Empirical Studies. International Regional Science Review, 26(2), 175-188. 
Brueckner, Jan K., \& Saavedra, Luz A. (2001). Do Local Governments Engage in Strategic Property-Tax Competition? National Tax Journal, 54(2), 203-230.

Cheshire, Paul C., \& Dericks, Gerard. (2014). 'Iconic Design' as Deadweight Loss: Rent Acquisition by Design in the Constrained London Office Market. SERC discussion paper 154.

Ciccone, Antonio. (2002). Agglomeration effects in Europe. European Economic Review, 46(2), 213-227.

Ciccone, Antonio, \& Hall, Robert E. (1996). Productivity and the Density of Economic Activity. American Economic Review, 86(1), 54-70.

Clark, William Clifford, \& Kingston, John Lyndhurst. (1930). The Skyscraper: A study of the Economic Height of Office Buildings. New York: American Institute of Steel Construction, inc.

Colwell, Peter F., Munneke, Henry J., \& Trefzger, Joseph W. (1998). Chicago's Office Market: Price Indices, Location and Time. Real Estate Economics, 26(1), 83-106.

Combes, Pierre-Philippe, Duranton, Gilles, \& Gobillon, Laurent. (2013). The Costs of Agglomeration: Land Prices in French Cities. Paris School of Economics Working Paper No 2013 - 28.

Combes, Pierre-Philippe, Duranton, Gilles, Gobillon, Laurent, Puga, Diego, \& Roux, Sébastien. (2012). The productivity advantages of large cities: Distinguishing agglomeration from firm selection. Econometrica, 80(6), 2543-2594.

Dekle, Robert, \& Eaton, Jonathan. (1999). Agglomeration and Land Rents: Evidence from the Prefectures. Journal of Urban Economics, 46(2), 200-214.

Department of the Environment. (1971). Local Authority Offices: Areas and Costs. London: DOE.

Eichholtz, Piet, Kok, Nils, \& Quigley, John M. (2008). Doing Well by Doing Good? Green Office Buildings. Berkeley Program on Housing and Urban Policy. Working Papers, W08-001.

Epple, Dennis, Gordon, Brett, \& Sieg, Holger. (2010). A New Approach to Estimating the Production Function for Housing. American Economic Review, 100(3), 905-924.

Fujita, Masahisa, \& Ogawa, Hideaki. (1982). Multiple equilibria and structural transition of nonmonocentric urban configurations. Regional Science and Urban Economics, 12(2), 161-196.

Giles, David E. A. (1984). Instrumental variables regressions involving seasonal data. Economics Letters, 14(4), 339-343.

Grimaud, A. (1989). Agglomeration economies and building height. Journal of Urban Economics, 25(1), 17-31.

Helsley, Robert W., \& Strange, William C. (2007). Urban interactions and spatial structure. Journal of Economic Geography, 7(2), 119-138.

Helsley, Robert W., \& Strange, William C. (2008). A game-theoretic analysis of skyscrapers. Journal of Urban Economics, 64(1), 49-64.

Henderson, J. Vernon, Kuncoro, Ari, \& Turner, Matt. (1995). Industrial Development in Cities. Journal of Political Economy, 103(5), 1067-1090.

Hoyt, Homer. (1933). One hundred years of land values in Chicago. Chicago: Chicago University Press.

Kau, James B., \& Sirmans, C. F. (1979). Urban Land Value Functions and the Price Elasticity of Demand for Housing. Journal of Urban Economics, 6(1), 112.

Koster, Hans R. A., van Ommeren, Jos, \& Rietveld, Piet. (2014). Is the sky the limit? High-rise buildings and office rents. Journal of Economic Geography, 14(1), 125-153.

Lawrence, Andrew. (1999). The Skyscraper Index: Faulty Towers. Property Report Dresdner Kleinwort Waserstein Research, January 15, 1999.

Lee, Jong-San, Lee, Hyun-Soo, \& Park, Moon-Seo. (2011). Schematic cost estimating model for super tall buildings using a high-rise premium ratio. Canadian Journal of Civil Engineering, 38(5), 530-545.

Liu, Crocker H., Rosenthal, Stuart S., \& Strange, William C. (2015). The Vertical City: Rent Gradients and Spatial Structure. Working Paper.

Long, Natalie. (2011). Burj Khalifa dining reaches new heights. Gulf News.

Lucas, Robert E., Jr., \& Rossi-Hansberg, Esteban. (2002). On the Internal Structure of Cities. Econometrica, $70(4), 1445-1476$.

McDonald, John F. (1981). Capital-land substitution in urban housing: A survey of empirical estimates. Journal of Urban Economics, 9(2), 190-211.

McDonald, John F., \& Bowman, H. Woods. (1979). Land value functions: A reevaluation. Journal of Urban Economics, 6(1), 25-41.

McMillen, Daniel P. (1996). One Hundred Fifty Years of Land Values in Chicago: A Nonparametric Approach. Journal of Urban Economics, 40(1), 100-124.

McMillen, Daniel P. (2006). Testing for Monocentricity. In R. J. Arnott \& D. P. McMillen (Eds.), A Companion to Urban Economics. Malden: Blackwell Publishing. 
McMillen, Daniel P., \& McDonald, J. F. (2002). Land Values in a Newly Zoned City. The Review of Economics and Statistics, 84(1), 62-72.

Mills, Edwin S. (1967). An Aggregative Model of Resource Allocation in a Metropolitan Area. The American Economic Review, 57(2), 197-210.

Mills, Edwin S. (1969). The value of urban land. In H. Perloff (Ed.), The quality of urban environment. Baltimore, MA: Resources for the Future, Inc.

Moretti, Enrico. (2004). Workers' Education, Spillovers, and Productivity: Evidence from Plant-Level Production Functions. American Economic Review, 94(3), 656-690.

Muth, Richard F. (1969). Cities and Housing: The Spatial Pattern of Urban Residential Land Use. Chicago: University of Chicago Press.

Rauch, James E. (1993). Productivity Gains from Geographic Concentration of Human Capital: Evidence from the Cities. Journal of Urban Economics, 34(3), 380-400.

Shilton, Leon, \& Zaccaria, Anthony. (1994). The avenue effect, landmark externalities, and cubic transformation: Manhattan office valuation. The Journal of Real Estate Finance and Economics, $8(2), 151-165$.

Silverman, B. W. (1986). Density Estimation For Statistics and Data Analysis. Monographs on Statistics and Applied Probability.

Smith, Brian, Dholakia, Mital, \& Heseltine, Richard. (2014). Cost model: Tall buildings. Building.

Sullivan, Arthur M. (1991). Tall buildings on cheap land: Building heights and intrabuilding travel costs. Journal of Urban Economics, 29(3), 310-328.

Sveikauskas, Leo A. (1975). The Productivity of Cities. The Quarterly Journal of Economics, 89(3), 393 413.

Tan, Willie. (1999). Construction cost and building height. Construction Management and Economics, 17(2), 129-132.

Tauranac, J. (1995). The empire state building: the making of a landmark. New York: Scribner.

United States Department of Agriculture. (2012). Soil Survey of Cook County, Illinois. The Natural Resources Conservation Service.

Yeates, Maurice H. (1965). Some Factors Affecting the Spatial Distribution of Chicago Land Values, 19101960. Economic Geography, 41(1), 57-70. 


\section{Appendix to Tall Buildings and Land Values: Height and Construction Cost Elasticities in Chicago, 1870 - 2010}

Version: September 2017

\section{Introduction}

This technical appendix complements the main paper by providing additional evidence and details on the data used. The appendix is not designed to stand alone or replace the main paper. Section 2 provides additional detail on the data. Section 3 presents estimates of CBD coordinates, LWR-IV estimates of the elasticity of height with respect to land price not reported in the main paper for brevity, and complementary evidence on the cost of height and the elasticity of floor area ratio with respect to land price for small residential buildings. Section 4 adds to the analysis of spatial interactions among developers.

\section{Data}

\subsection{Tallest buildings}

Table A1 and Figure A1 present the tallest buildings of their times in Chicago since the 1850s. Typical for the period, the tallest buildings were churches up until the late $19^{\text {th }}$ century. The first commercial building to carry the title of the tallest building in Chicago was the Board of Trade building constructed in 1885 and demolished in 1929. Most of the buildings that were the tallest at their time held their leading position for at least ten years. The exceptions are the John Hancock Center and its successor the Aon Center (formerly the Amoco Building), which both were replaced as tallest buildings within a small number of years. The latter was replaced by the Willis Tower (formerly Sears Tower) in 1974, which is still the tallest building in the city. On average, the tallest buildings

* London School of Economics and Political Sciences (LSE) and Centre for Economic Policy Research (CEPR), Houghton Street, London WC2A 2AE, g.ahlfeldt@lse.ac.uk, www.ahlfeldt.com

- University of Illinois at Urbana-Champaign, Department of Economics, 214 DKH, 1407 W. Gregory Dr., Urbana, IL 61801, mcmillen@illinois.edu. 
remained in the leading position for slightly more than 20 years, which is perhaps suggestive of overbuilding and dissipative height competition.

Tab A1. Ever tallest buildings in Chicago since the 1850s

\begin{tabular}{|c|c|c|c|c|}
\hline No. & Name & Construction year & Years being the tallest & Height $(\mathrm{m})$ \\
\hline 1 & Holy Name Cathedral & 1854 & 19 & 75 \\
\hline 2 & St. Michael Church & 1873 & 12 & 88 \\
\hline 3 & Board of Trade Building & 1885 & 39 & 98 \\
\hline 4 & Chicago Temple Building & 1924 & 31 & 173 \\
\hline 5 & One Prudential Plaza & 1955 & 14 & 278 \\
\hline 6 & John Hancock Center & 1969 & 4 & 344 \\
\hline 7 & Aon Center & 1973 & 1 & 346 \\
\hline 8 & Willis Tower & 1974 & 41 & 442 \\
\hline
\end{tabular}

Notes: Source: (C) Emporis

Fig. A1. Tallest buildings in Chicago since the 1850s

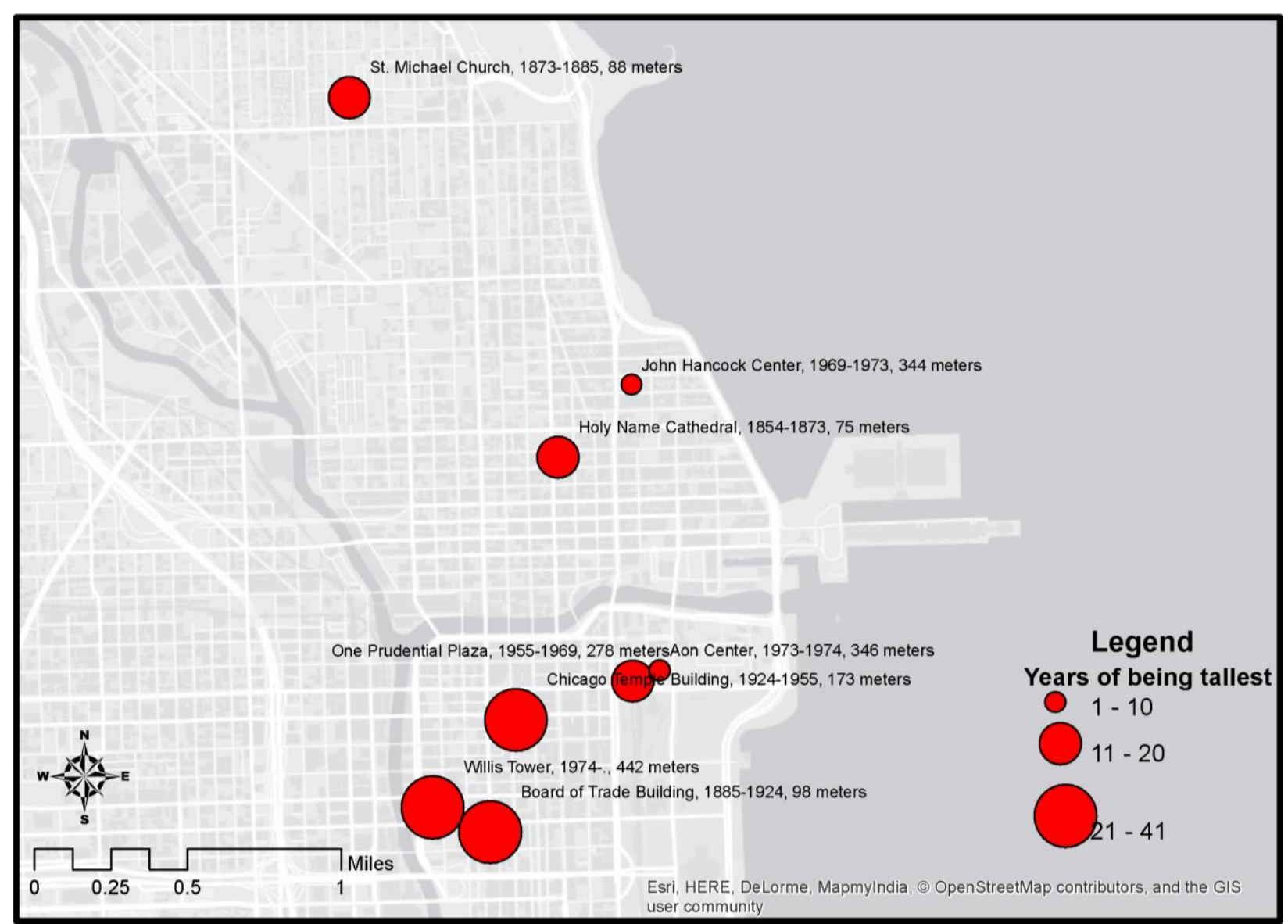

Notes: Own illustration based on (C) Emporis.com and base maps from (C) OpenStreetMap, accessed via the ESRI ArcGIS Online service.

\subsection{Olcott's Land Values - Blue Book of Chicago}

With nine cross-sections spreading from 1913 to 1990, Olcott's Blue Books provide the core of the land price data used in this paper. The section provides a brief summary of the nature and the collection of Olcott's land value data. A detailed discussion is in Ahlfeldt et al. (2012). 
The series Olcott's Land Values - Blue Book of Chicago reports land values for Chicago, Illinois, and was originally established in 1900. In the beginning George C. Olcott only published individual subsections of Chicago on a monthly basis. He later switched to the annual issues of books covering the entire city area plus the surrounding suburbs of Cook County. Land values were collected and published until the first half of the 1990s. Olcott's Blue Books were "designed by means of valuation maps to enable one to determine the approximate values of lots in each block of the city" (Olcott 1913). The reported land values are conservative, "impartial estimates" (Olcott 1913) based on sales, bids, and asking prices as well as on opinions of people working in real estates. The value collection involved a careful exploration of the territory, interviews with local dealers, and consolations of data on sales, leases, etc. They are supposed to reflect the current market value of pure land and to follow actual market transactions.

The data collection begins with scanning and geo-referencing the various map pieces provided in each Olcott's edition. The actual data extraction process involves two steps. In the first step, we create a shapefile that describes the spatial geometry of the land value data, typically using polylines drawn along stretches of streets having identical land values. The next step involves the data entry. For each polyline, the respective land value reported on the Olcott's map is entered into an attribute table that underlies the electronic polyline map. In some cases, Olcott's aggregates standard front foot values for presumably homogenous areas. For these areas, only the minimum and the maximum values are reported. In these cases, we draw polygons around these areas and assign the mean value that is representative for the area.

In the last step of the data extraction procedure, we aggregate land values to a spatial grid. The grid approach has various advantages: it is not density biased, it embodies the underlying grid structure of the city, and yet the areal units remain consistent over time and space. Each individual grid measures a size of $330 \times 330$ feet which is $1 / 256$ of a square mile. As each map piece measures $1 \times$ 1.5 miles it covers exactly 384 grid squares. Figure A2 illustrates Olcott's land values as presented in the Blue Book (left) along with the outcome of our digitization procedure. 
Fig. A2. Olcott's: Raw data versus output
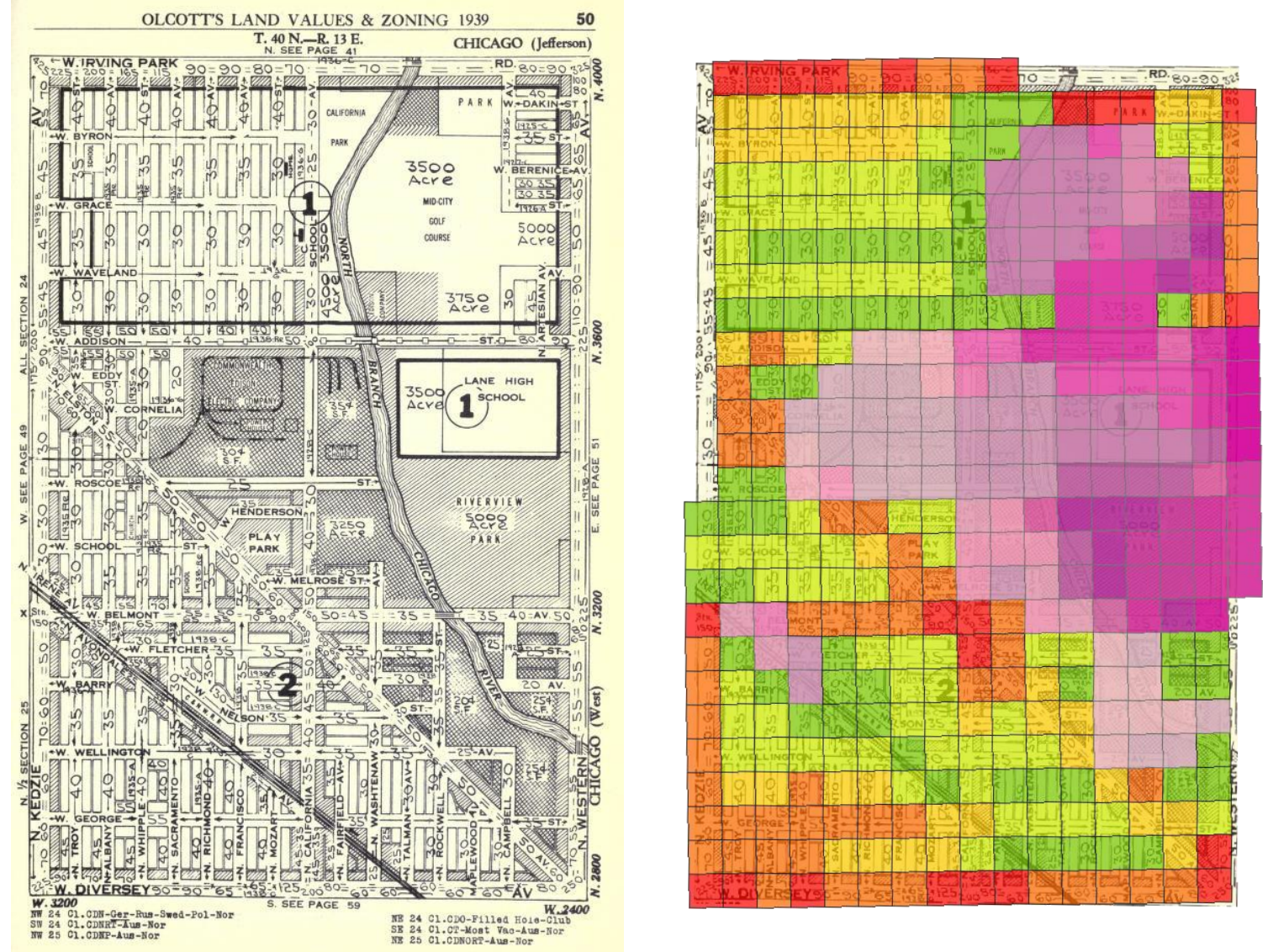

Notes: Standard street front foot values are shaded from green to red. Industrial land values are shaded from light to dark purple. Source: Ahlfeldt et al. (2012).

\subsection{Hoyt's land values}

As described in the main paper we rely on Hoyt (1933) to approximate land values for 1873 and 1893. In general, Hoyt's maps look similar to Olcott's maps described above. The maps are as detailed as Olcott's maps for the CBD. Outside the downtown area, Hoyt's land values are more aggregated and typically refer to rectangular segments of about a square mile. Figure A3 illustrates the 1873 raw data as reported in Hoyt (1933). 
Fig. A3. Hoyt's land values: 1873
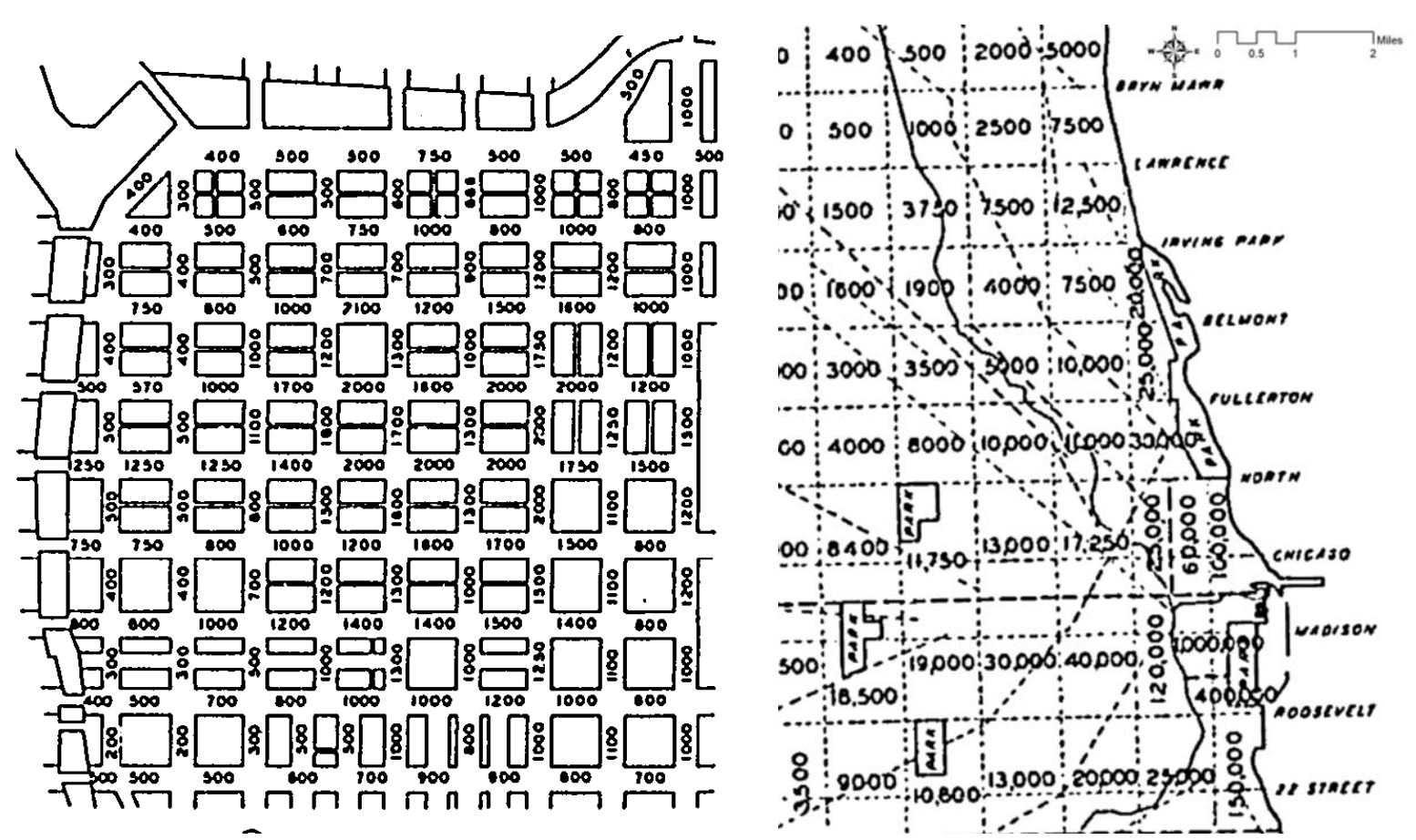

Notes: The left panel shows Hoyt's land values for the CBD section, roughly corresponding to the "Loop". The right panel shows a representative section of the remaining area. Source: Hoyt (1933).

To digitize these data, we use the same techniques as for the extraction of the Olcott data, which we described in the previous sub-section. However, because of the more aggregated nature of the Hoyt data outside the CBD we require an additional step to approximate land values at a sufficiently fine geographic scale. As discussed in the main paper we use locally weighted regression techniques to process the raw data reported in Hoyt. In particular, we seek to incorporate the spatial detail provided by Olcott for the developed areas outside the CBD and to smooth out the discrete changes in land values across the boundaries of the rectangular land value zones outside the developed area.

To apply these techniques, we require a definition of the areas that were developed in 1873 and 1893. Hoyt provides a map illustrating the boundaries of the settled area in 1873 and the growth in the settled area from 1873 to 1893. Our approach to digitizing this information is similar to our processing of the land value data. We begin by geo-referencing a scan of the map. We then manually draw polygons around the shaded areas in GIS because the low resolution of the original print complicates the application of automated extraction processes based on color recognition. Last, we merge the resulting polygons with the $330 \times 330$ foot grid described in the previous sub-section. If a geographic centroid of a grid cell falls within the boundaries of the extracted settled area in a given year, we code that grid cell as developed. Otherwise, it is coded as undeveloped. Figure A4 illustrates the settled area as presented in Hoyt as well as the resulting output after processing the raw data in GIS. 
Fig. A4. Settled area in 1873 and 1893
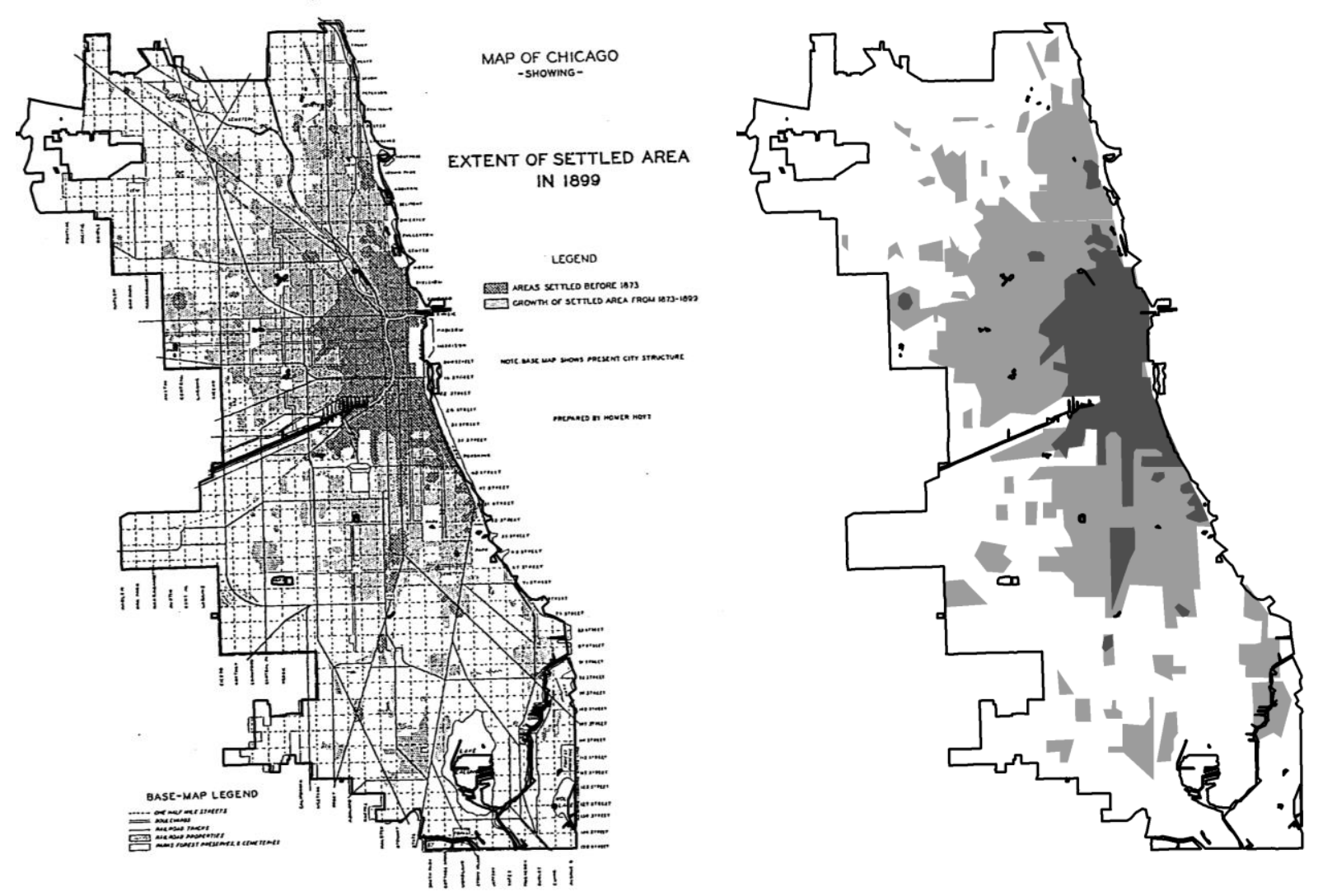

Notes: The left panel shows the settled area before 1873 and the growth between 1873 and 1893 as illustrated by Hoyt (1933). The right panel shows the outcome after processing in GIS. Dark shaded polygons approximate the settled area in 1873. The light and dark shaded areas combined approximate the settled area in 1893. Chicago city boundaries are illustrated by the thick black lines.

\section{A simple model of profit-maximizing building height}

The purpose of this section is to illustrate that the elasticity of height with respect to land price summarizes an equilibrium condition that can be derived from a simple model in which developers set the height to maximize profits.

In the absence of strategic interactions, developers face a relatively simple problem when choosing the optimal building height. Given an average price of floor space $p$, the revenue a building generates per unit of footprint is $p S$, where $S$ is a measure of building height (net floor space over footprint). While the average price of floor space depends directly on the height of a building, it may also depend on location factors $X$ relating to agglomeration, amenities, and other site-specific factors (Liu et al., 2015), i.e. $p(S, X)=p\left(p_{0}(X), S\right)$, where $\frac{\partial p}{\partial S}>0$, and $p_{0}$ is a baseline floor space price. The average construction cost per unit of floor space increases in height at an increasing rate be- 
cause taller buildings require more sophisticated structural engineering, expensive building materials, and additional facilities such as elevators. ${ }^{1}$ Costs also depend on locational factors $Z$ that all else equal make it more or less expensive to build tall, i.e. $c(S, Z)$, with $\frac{\partial c}{\partial S}>0, \frac{\partial^{2} c}{\partial S}>0$.

The profit function is then defined as:

$\pi=p\left(p_{o}(X), S\right) S-c(Z, S) S-\frac{1}{a(S)} r$

, where $0<a(S) \leq 1, \frac{\partial a}{\partial S}<0$ is the fraction of a land parcel that the tall building occupies. This function captures the idea that for every unit of the building footprint of a tall building the developer needs to purchase additional land to provide parking space, driveways, amenities such as green spaces and playgrounds or simply some clearance space to other buildings. Because taller buildings host more employees and residents, such "extra space" is likely to depend on the height of the tall structure.

Developers maximize profits and find the efficient height by setting marginal revenues equal to marginal costs. As long as $p(S=0)>c(S=0)$ and $\frac{\partial^{2} p(S)}{\partial S}<\frac{\partial^{2} c(S)}{\partial S}$ there is a single solution for the efficient height $S^{*}=f\left(p_{0}(X), Z\right)$. The efficient height is, thus, determined by the interplay of supply side factors (the shape of the construction cost function as well as locational features) and the various factors that shape demand for space (internal and external agglomeration and amenities). Since in equilibrium there is a unique mapping we can express the ground floor space price for an equilibrium building as a function of the equilibrium height $p_{0}\left(S^{*}, Z\right)=f^{-1}\left(S^{*}, Z\right)$. In spatial equilibrium with free entry and exit there are zero economic profits, the profit function can thus be written as:

$\pi=p\left(f^{-1}\left(S^{*}, Z\right), S^{*}\right) S^{*}-c\left(Z, S^{*}\right) S^{*}-\frac{1}{a\left(S^{*}\right)} r^{*}=0$

It follows that height can be expressed solely as a function of the land price, which adjusts to ensure zero profits, and features of the site that affect the relative construction cost of tall buildings.

$S^{*}=g\left(r^{*}, Z\right)$

This equilibrium relationship excludes locational demand side parameters. The intuition is that the land price is a residual in the profit function. Any factors that increase the floor space price will

1 For a theoretical discussion, see Ferry and Brandon (1980) and Seeley (1983). 
increase the profitable building height. Taller buildings generate more profits per land unit. Through the collective bidding process that equalizes profits, these profits eventually capitalize into the land price. In equilibrium, locational factors such as amenities and agglomeration affect both heights and land prices, but it is the shape of the construction cost function and the extent to which extra space depends on building height that determine the functional relationship between height and land price.

To obtain a parametric equivalent to equation (A3), we choose convenient parametrizations for the floor space price function $p(S)=p S^{\omega}$ and the construction cost function $c(S, Z)=c S^{\theta(Z)}$, where $p$ and $c$ are scale factors and $\omega>0, \theta(Z)>0, \theta(Z)>\omega$ monitor the degree of convexity of the price and cost functions. After expressing the developable land fraction to be $a(S)=l S^{-\lambda}$, where $\lambda \geq 0$ represents the extra space elasticity, the (zero-)profit function is then defined as:

$\pi=p S^{1+\omega}-c S^{1+\theta}-\frac{1}{l S^{-\lambda}} r=0$

Solving the first-order condition for $p$ and substituting the result into (A4) implies the following log-linearized relationship between the fundamental height and the land price:

$\ln (S)=-\frac{1}{1+\theta-\lambda}\left(\ln (l)+\ln (c)+\ln \left(\frac{\theta-\omega}{\omega-1}\right)\right)+\frac{1}{1+\theta-\lambda} \ln (r)$

Specification (A5) motivates the reduced-from empirical specification (6) in the main paper. The elasticity of height with respect to land price is defined as $\beta=1 /(1+\theta-\lambda)$. Evidently, this is a special case of the more general formulation in the main paper in which $\sigma=1$. This is the expected result as in this derivation we have treated a unit of floor space as a homogeneous good and abstracted from complementarities with land for the sake of simplicity. The main insight from equation (A5) is that a simple model of profit-maximizing development leads to an equilibrium relationship between height and land price that depends exclusively on supply-side parameters in a way that is consistent with the interpretations presented in the main paper.

Equation (A5) also describes the effect of a positive height premium in floor space prices that was found by Liu et al. (2015). While a positive height elasticity of floor space prices $(\omega)$ increases the profitable building height, leading to taller buildings, it does not affect the height elasticity. 


\section{The spatial structure of building height}

\subsection{CBD location}

At various stages of the empirical analysis in the main paper we make use of a measure that captures proximity to the CBD. We identify this CBD as the nucleus of log-linear height and land price gradient in auxiliary NLLS estimations, which we run separately for each construction cohort.

$\ln \left(C_{i t}\right)=\gamma_{0 t}+\gamma_{1 t}\left(\left(X_{i t}-\gamma_{t}^{X}\right)^{2}+\left(Y_{i t}-\gamma_{t}^{Y}\right)^{2}\right)^{0.5}+\epsilon_{i t}$,

where $C_{i t}$ is either the height of a building $i$ constructed in a decade $t$ or the price of the underlying plot of land, $X_{i t}$ and $Y_{i t}$ are cartesian coordinates of buildings (in projected miles), and $\gamma_{t}^{X}$ and $\gamma_{t}^{Y}$ are the coordinates of the CBD to be estimated along with the other parameters $\gamma_{0 t}$ and $\gamma_{1 t}$.

Parametric estimates are presented in Tables A2 and A3. As expected there is a negative relationship between height and land price on the one hand and the distance from the nucleus of the gradients on the other in virtually all years $\left(\gamma_{1 t}<0\right)$. The exception is the $1940 \mathrm{~s}$ cohort, which is a period of sparse data and limited construction activity in the CBD (see also Figure 5 in the main paper).

We plot the locations identified by the estimated coordinates in Figure A5. In general, our estimates suggest that the center of gravity of the city has changed very little over time. Virtually all estimated CBD locations, based on height and land price data, are located within less than a square mile. The majority of estimated CBD locations are around the intersection of Washington Street and State Street, which we therefore choose as CBD in all years. Notably, the traditional center of Chicago, at the intersection of State and Madison Street, is only one block south of the site identified using this procedure. 
Fig. A5. Estimated CBD coordinates

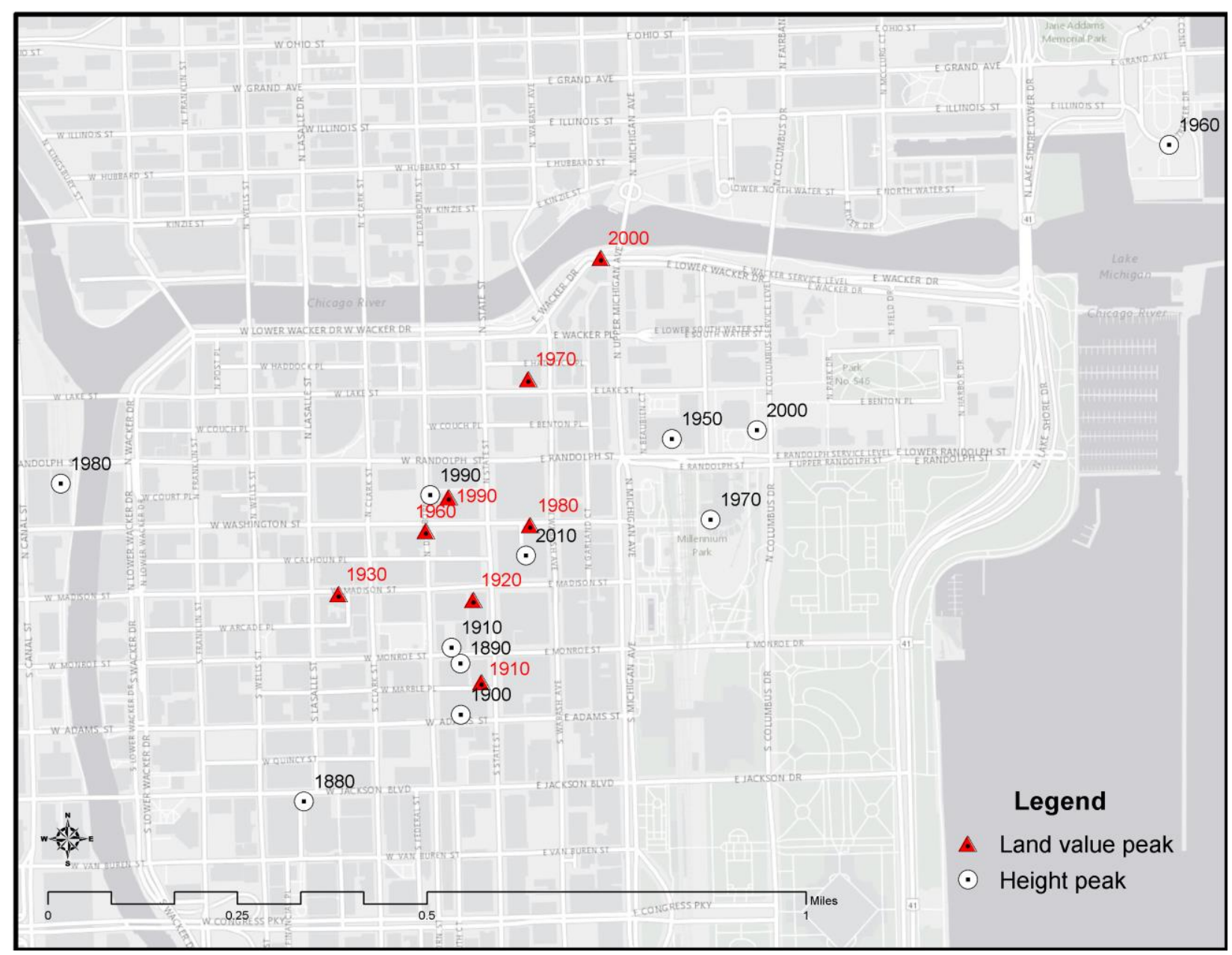

Notes: Base maps from (c OpenStreetMap, accessed via the ESRI ArcGIS Online service. 
Tab A2. NLS estimates of CBD coordinates - land price

\begin{tabular}{|c|c|c|c|c|c|c|c|c|c|c|c|c|c|}
\hline \multirow[b]{3}{*}{ Cohort } & (1) & $(2)$ & (3) & (4) & (5) & (6) & $(7)$ & (8) & (9) & (10) & (11) & $(12)$ & (13) \\
\hline & \multicolumn{13}{|c|}{ Log building height } \\
\hline & $\begin{array}{l}1870 s \text { \& } \\
1880 s\end{array}$ & $\begin{array}{l}\text { 1890s \& } \\
1900 s\end{array}$ & $1910 \mathrm{~s}$ & $1920 \mathrm{~s}$ & 1930s & 1940s & 1950s & $1960 \mathrm{~s}$ & 1970s & 1980s & $1990 \mathrm{~s}$ & $2000 \mathrm{~s}$ & $2010 s$ \\
\hline$\gamma_{0}$ (intercept) & $\begin{array}{l}-0.378^{*} \\
(0.209)\end{array}$ & $\begin{array}{l}0.859^{* * *} \\
(0.095)\end{array}$ & $\begin{array}{l}1.985^{* * *} \\
(0.069)\end{array}$ & $\begin{array}{l}2.793^{* * *} \\
(0.044)\end{array}$ & $\begin{array}{l}2.393^{* * *} \\
(0.112)\end{array}$ & $\begin{array}{l}-16.545 \\
(101.51)\end{array}$ & $\begin{array}{l}66.24^{* * *} \\
(20.533)\end{array}$ & $\begin{array}{l}1.526^{* * *} \\
(0.097)\end{array}$ & $\begin{array}{l}3.063^{* * *} \\
(0.092)\end{array}$ & $\begin{array}{l}3.443^{* * *} \\
(0.086)\end{array}$ & $\begin{array}{l}4.271^{* * *} \\
(0.096)\end{array}$ & $\begin{array}{l}5.453^{* * *} \\
(0.052)\end{array}$ & $\begin{array}{l}4.623^{* * *} \\
(0.143)\end{array}$ \\
\hline $\begin{array}{l}\gamma_{1}(C B D \text { distance elas- } \\
\text { ticity) }\end{array}$ & $\begin{array}{l}-1.784^{* * *} \\
(0.389)\end{array}$ & $\begin{array}{l}-1.502^{* * *} \\
(0.067)\end{array}$ & $\begin{array}{l}-1.189^{* * *} \\
(0.052)\end{array}$ & $\begin{array}{l}-0.664^{* * *} \\
(0.03)\end{array}$ & $\begin{array}{l}-0.574^{* * *} \\
(0.072)\end{array}$ & $\begin{array}{l}5.292 \\
(25.321)\end{array}$ & $\begin{array}{l}-20.45^{* * *} \\
(5.042)\end{array}$ & $\begin{array}{l}-0.687^{* * *} \\
(0.068)\end{array}$ & $\begin{array}{l}-0.964^{* * *} \\
(0.074)\end{array}$ & $\begin{array}{l}-1.100^{* * *} \\
(0.074)\end{array}$ & $\begin{array}{l}-1.267^{* * *} \\
(0.081)\end{array}$ & $\begin{array}{l}-1.315^{* * *} \\
(0.045)\end{array}$ & $\begin{array}{l}-0.481^{* * *} \\
(0.13)\end{array}$ \\
\hline$\gamma^{x}(x$-coordinate $)$ & $\begin{array}{l}222.4^{* * *} \\
(0.083)\end{array}$ & $\begin{array}{l}222.8^{* * *} \\
(0.015)\end{array}$ & $\begin{array}{l}222.8^{* * *} \\
(0.021)\end{array}$ & $\begin{array}{l}222.8^{* * *} \\
(0.042)\end{array}$ & $\begin{array}{l}222.6^{* * *} \\
(0.132)\end{array}$ & $\begin{array}{l}199.7^{* *} \\
(90.364)\end{array}$ & $\begin{array}{l}246.0^{* * *} \\
(5.4)\end{array}$ & $\begin{array}{l}222.7^{* * *} \\
(0.064)\end{array}$ & $\begin{array}{l}222.8^{* * *} \\
(0.1)\end{array}$ & $\begin{array}{l}222.9^{* * *} \\
(0.057)\end{array}$ & $\begin{array}{l}222.6^{* * *} \\
(0.052)\end{array}$ & $\begin{array}{l}222.9^{* * *} \\
(0.033)\end{array}$ & $\begin{array}{l}222.9^{* * *} \\
(0.228)\end{array}$ \\
\hline$\gamma^{\gamma}$ (y-coordinate) & $\begin{array}{l}359.8^{* * *} \\
(0.059)\end{array}$ & $\begin{array}{l}359.8^{* * *} \\
(0.015)\end{array}$ & $\begin{array}{l}359.8^{* * *} \\
(0.014)\end{array}$ & $\begin{array}{l}359.9^{* * *} \\
(0.042)\end{array}$ & $\begin{array}{l}359.9^{* * *} \\
(0.08)\end{array}$ & $\begin{array}{l}350.0^{* * *} \\
(34.979)\end{array}$ & $\begin{array}{l}368.8^{* * *} \\
(1.9)\end{array}$ & $\begin{array}{l}360.0^{* * *} \\
(0.046)\end{array}$ & $\begin{array}{l}360.2^{* * *} \\
(0.092)\end{array}$ & $\begin{array}{l}360.0^{* * *} \\
(0.053)\end{array}$ & $\begin{array}{l}360.2^{* * *} \\
(0.048)\end{array}$ & $\begin{array}{l}360.3^{* * *} \\
(0.033)\end{array}$ & $\begin{array}{l}360.9^{* * *} \\
(0.168)\end{array}$ \\
\hline Observations & 17 & 90 & 90 & 309 & 66 & 18 & 110 & 271 & 167 & 131 & 99 & 314 & 55 \\
\hline$R^{2}$ & 0.819 & 0.858 & 0.863 & 0.623 & 0.587 & 0.257 & 0.531 & 0.29 & 0.522 & 0.672 & 0.751 & 0.756 & 0.228 \\
\hline$A I C$ & 40.1 & 208.3 & 169.1 & 605.5 & 139.6 & 53.3 & 297.3 & 830.7 & 459.8 & 328.3 & 255.4 & 739.2 & 159.2 \\
\hline
\end{tabular}

Notes: Unit of observation is new constructions. Standard errors in parentheses. ${ }^{*} p<0.1,{ }^{* *} p<0.05,{ }^{* * *} p<0.01$

Tab A3. NLS estimates of CBD coordinates - building height

\begin{tabular}{|c|c|c|c|c|c|c|c|c|c|c|c|c|c|}
\hline & (1) & (2) & (3) & (4) & (5) & (6) & $(7)$ & (8) & (9) & (10) & $(11)$ & $(12)$ & (13) \\
\hline & \multicolumn{13}{|c|}{ Log land price } \\
\hline \multirow[t]{2}{*}{ Cohort } & 1870s \& & 1890s \& & $1910 \mathrm{~s}$ & $1920 \mathrm{~s}$ & $1930 \mathrm{~s}$ & 1940s & $1950 \mathrm{~s}$ & $1960 \mathrm{~s}$ & $1970 \mathrm{~s}$ & 1980s & $1990 \mathrm{~s}$ & $2000 s$ & $2010 s$ \\
\hline & $1880 \mathrm{~s}$ & $1900 \mathrm{~s}$ & & & & & & & & & & & \\
\hline \multirow[t]{2}{*}{$V_{0}$ (intercept) } & $3.656^{* * *}$ & $3.631^{* * *}$ & $3.678^{* * *}$ & $4.101^{* * *}$ & $4.728^{* * *}$ & $-478.93^{*}$ & $4.211^{* * *}$ & $4.389^{* * *}$ & $4.510^{* * *}$ & $4.424^{* * *}$ & $4.171^{* * *}$ & $4.242^{* * *}$ & $4.364^{* * *}$ \\
\hline & $(0.21)$ & $(0.05)$ & $(0.036)$ & $(0.041)$ & $(0.345)$ & $(269.53)$ & (0.059) & $(0.036)$ & $(0.062)$ & $(0.049)$ & $(0.1)$ & $(0.042)$ & $(0.095)$ \\
\hline $\begin{array}{l}\gamma_{1}(C B D \text { distance elas- } \\
\text { ticity) }\end{array}$ & $\begin{array}{l}0.843^{* *} \\
(0.382)\end{array}$ & $\begin{array}{l}-0.200^{* * *} \\
(0.035)\end{array}$ & $\begin{array}{l}-0.258^{* * *} \\
(0.028)\end{array}$ & $\begin{array}{l}-0.255^{* * *} \\
(0.027)\end{array}$ & $\begin{array}{l}-0.653^{* * *} \\
(0.168)\end{array}$ & $\begin{array}{l}73.867^{*} \\
(41.237)\end{array}$ & $\begin{array}{l}-0.236^{* * *} \\
(0.042)\end{array}$ & $\begin{array}{l}-0.193^{* * *} \\
(0.025)\end{array}$ & $\begin{array}{l}-0.242^{* * *} \\
(0.046)\end{array}$ & $\begin{array}{l}-0.307^{* * *} \\
(0.043)\end{array}$ & $\begin{array}{l}-0.473^{* * *} \\
(0.075)\end{array}$ & $\begin{array}{l}-0.566^{* * *} \\
(0.035)\end{array}$ & $\begin{array}{l}-0.502^{* * *} \\
(0.100)\end{array}$ \\
\hline \multirow[t]{2}{*}{$\gamma^{x}(x$-coordinate $)$} & $222.0^{* * *}$ & $222.8^{* * *}$ & $222.7^{* * *}$ & $223.0^{* * *}$ & $224.2^{* * *}$ & -463.0 & $223.0^{* * *}$ & $222.8^{* * *}$ & $223.1^{* * *}$ & $222.3^{* * *}$ & $223.0^{* * *}$ & 223. $2^{* * *}$ & $222.8^{* * *}$ \\
\hline & $(0.284)$ & $(0.062)$ & $(0.035)$ & $(0.123)$ & $(0.842)$ & (.) & $(0.213)$ & $(0.122)$ & $(0.258)$ & $(0.072)$ & $(0.182)$ & $(0.062)$ & $(0.195)$ \\
\hline \multirow[t]{2}{*}{$\gamma^{Y}(y$-coordinate $)$} & $360.5^{* * *}$ & $359.8^{* * *}$ & $359.8^{* * *}$ & $360.1^{* * *}$ & $359.1^{* * *}$ & $334.2^{* * *}$ & $360.1^{* * *}$ & $360.2^{* * *}$ & $360.1^{* * *}$ & $359.9^{* * *}$ & $360.1^{* * *}$ & $360.1^{* * *}$ & $360.0^{* * *}$ \\
\hline & $(0.234)$ & $(0.056)$ & $(0.051)$ & $(0.091)$ & $(0.654)$ & $(103.61)$ & $(0.18)$ & $(0.101)$ & $(0.066)$ & $(0.061)$ & $(0.13)$ & $(0.068)$ & $(0.134)$ \\
\hline Observations & 17 & 90 & 90 & 309 & 66 & 18 & 110 & 271 & 167 & 131 & 99 & 314 & 55 \\
\hline$R^{2}$ & 0.281 & 0.279 & 0.515 & 0.372 & 0.512 & 0.233 & 0.361 & 0.207 & 0.225 & 0.316 & 0.393 & 0.505 & 0.345 \\
\hline$A / C$ & 30.3 & 92.7 & 52.2 & 284.5 & 80.9 & 16.1 & 56.6 & 261 & 239.4 & 214.2 & 201.9 & 509.9 & 115.4 \\
\hline
\end{tabular}

Notes: Unit of observation is new constructions. Standard errors in parentheses. ${ }^{*} p<0.1,{ }^{* *} p<0.05,{ }^{* * *} p<0.01$ 


\subsection{The elasticity of height with respect to land price: Alternative in- struments}

In model (6) of Table 5 in the main paper, distance from the CBD, distance from Lake Michigan, and a dummy for locations within 0.1 miles from Chicago River are used as instruments for land prices when estimating the elasticity of height with respect to land price. With this approach, we address two potential concerns. For one thing, the assessors (Olcott's) may have been influenced in their appraisal by the construction of a tall building at a given location (a reverse-causality problem). Second, it is theoretically possible that unobserved supply-side factors affect building heights and land prices at the same time. The instruments address both concerns to the extent that the spatial variables influence land prices via a demand-side amenity channel exclusively. In columns (1-6) in Table A4 below, we present several robustness checks in which we use subsets of the three instrumental variables. The height elasticity estimates generally remain close to the baseline result in Table 5, column (6) in all models.

In the last column, we use lagged (by one cohort) land prices as an instrument. This instrument primarily addresses the reverse-causality concern. To ensure that the IV estimates are identified from the same set of cohorts as the other IV estimates and the OLS estimates, we use the actual land prices instead of the lagged prices (which are not available) of the 1870 cohort in the instrument. The technologies required for cost-effective construction of tall residential and commercial buildings were yet to be developed in 1870 . Therefore, the reverse-causality problem is unlikely to exist within that cohort. As with the baseline IV strategy, the height elasticity estimate remains close to the baseline result. 
Tab A4. Elasticity of density with respect to land price: IV models

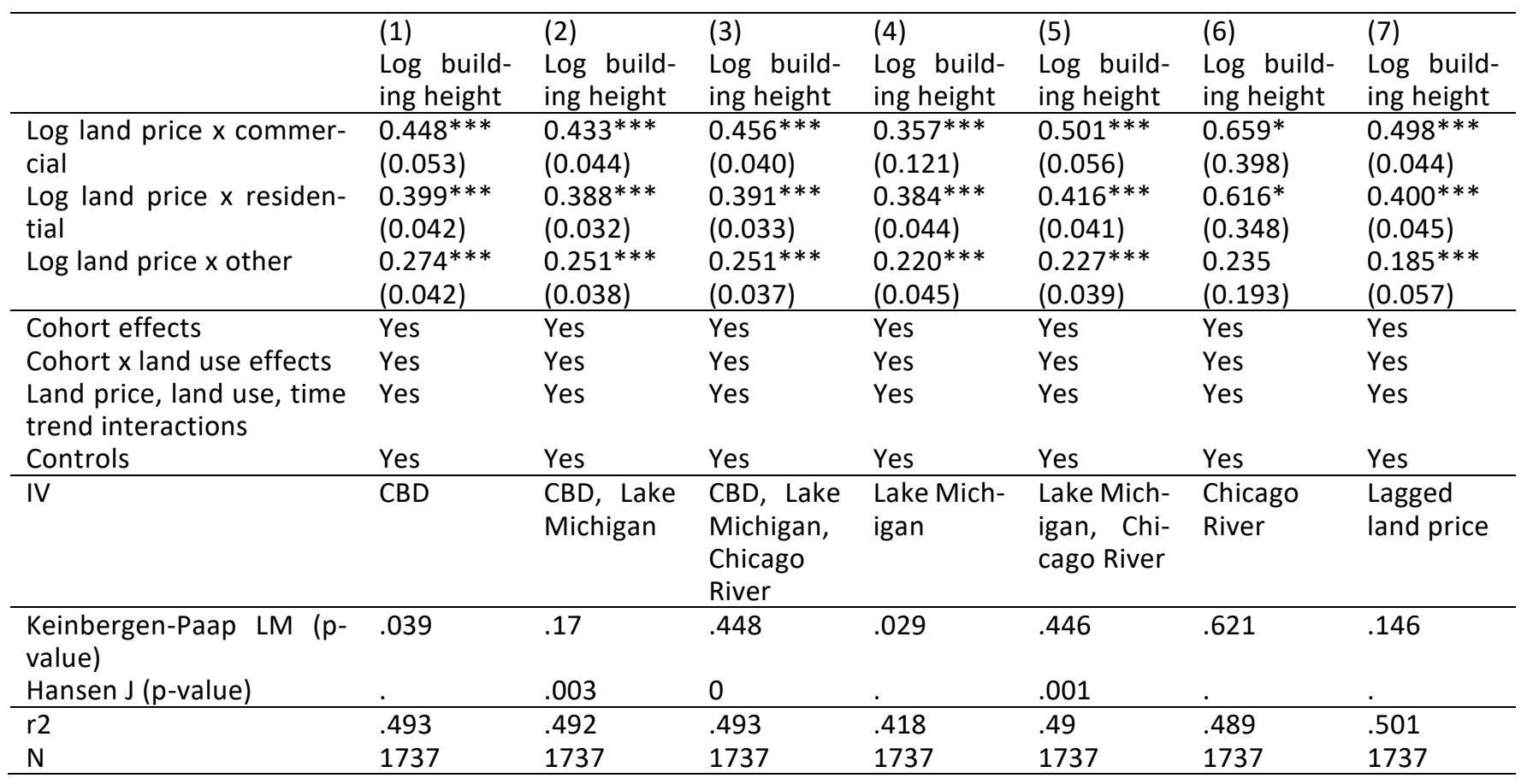

Notes: 2SLS estimates. Model (3) is identical to model (6) in Table 5 in the main paper. Standard errors are clustered on construction date cohorts (decades). Controls include dummies for the following categories: retail, hotel, warehouse, public use, cultural facility, sports facility. CBD / Lake Michigan / Chicago River instruments for land price are log distance from the CBD / log distance from Lake Michigan / within 0.1 mile from Chicago River throughout columns (1) to (6). Interactions of the instruments and land use indicators as well as time trends are used to instrument of land price interaction terms. In column (7), land prices lagged by one (decadal) cohort (the same cohort for the 1870 cohort) are used as an instrument. ${ }^{*} p<0.1,{ }^{* *} p<0.05,{ }^{* * *} p<0.01$

\subsection{The elasticity of height with respect to land price: LWR estimates vs. building characteristics}

In Figure 8 in the main paper we plot the LWR elasticity estimates (based on baseline model Table 5, column (5) in the main paper) against the year of construction. In Figure A6 below, we similarly correlate the local height elasticity estimates with distance from the CBD, building height, land price and the floor area ratio. Unlike for the time trend, we do not find strong correlations with any of those variables. 
Fig. A6. The elasticity of height with respect to land price: LWR estimates vs. building characteristics
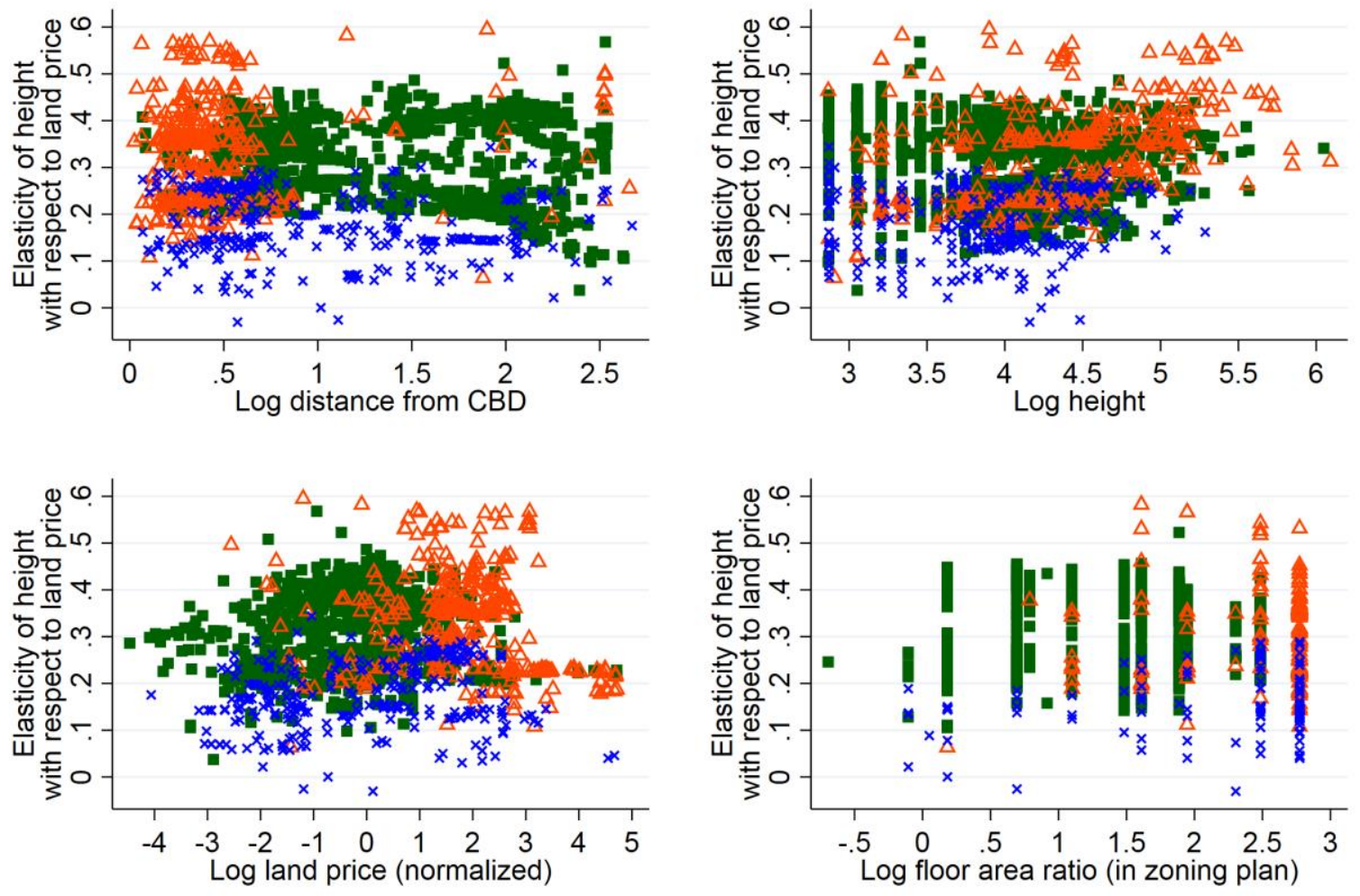

- Residential $\triangle$ Commercial $\times$ Other

Notes: Each icon in each panel represents a LWR estimate of the elasticity of height with respect to land price for a given building $\tilde{\imath}$ built in year $\tilde{t}$. A small number of outliers is excluded to improve readability. The regression model is the same as in Table 5, column (5). Observations are weighted using Gaussian kernel weights based on the geographic distance from $\tilde{l}$ and the time distance from $\tilde{t}$. The bandwidth is selected according to the Silverman (1986) rule. Floor area ratio data are discussed in section 4.5 in this appendix. LWR are run separately for the periods 1870-1919, 1920-1956, and 1957-2014.

\subsection{The elasticity of height with respect to land price: LWR-IV estimates}

As discussed in the main paper in Section 3.3 and in Section 3.2 of this appendix we use an instrumental variable strategy to address potential reverse-causality and omitted variable problems. In Table A7, we present an instrumental variable variant of Figure 8 in the main paper, which combines the LWR estimation technique with the instrumental variables from Table 5, model (6) in the main paper. The results are qualitatively and quantitatively similar to the baseline results reported in the main paper (Figure 8). In line with the parametric IV models in Table 5, the most notable difference is that the residential height elasticity estimates are somewhat larger. 
Fig. A7. LWR-IV Estimates

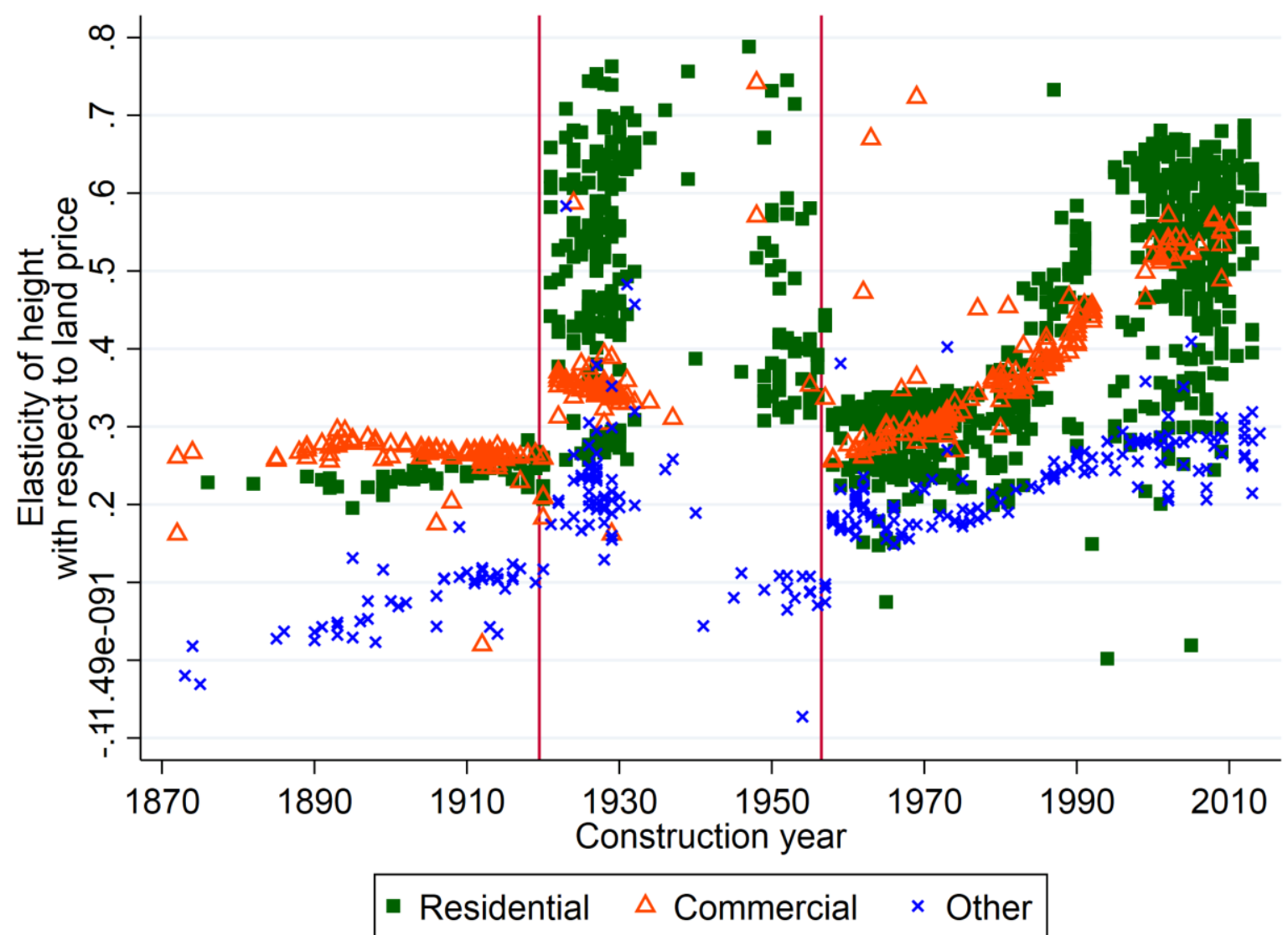

Notes: Figure shows an IV version of Figure 8 in the main paper. Each icon represents an LWR estimate of the elasticity of height with respect to land price for a given building $\tilde{\imath}$ built in year $\tilde{t}$. Observations are weighted using Gaussian kernel weights based on the geographic distance from $\tilde{\imath}$ and the time distance from $\tilde{t}$. The bandwidth is selected according to the Silverman (1986) rule. Distance from the CBD, distance from Lake Michigan and a dummy for distances within 0.1 miles from Chicago River are used as an instrument for land prices.

\subsection{The elasticity of height with respect to land price: the role of zoning}

As summarized by Barr (2013), the zoning regime in Chicago changed over time. From 1893 to 1920, explicit building height limits in the range of 130 to 200 feet (40 to 79 meters) were in place. In 1920, these height limits were relaxed significantly as towers were allowed to be as tall as 183 meters. In 1923, the height regulation was removed altogether. Since then, there has been no general building height limit in Chicago. However, in 1942 a regulation was introduced that linked the legally allowed maximum building height to the size of the lot. According to Barr (2013), this regulation roughly corresponded to a floor area ratio (FAR) limit of 12 . This regulation was of little practical relevance, however, because in the aftermath of the great depression hardly any super-tall buildings were constructed. A zoning ordinance has been in place since 1957 that defines maximum legally allowed FAR for distinct types of zoning districts. The FAR limits range from 0.5 to 16 . In 
selected high-density areas, FAR limits are negotiable as developers can obtain FAR bonuses in return for providing public amenities such as open spaces.

Figure A8 illustrates the evolution of the heights of tall buildings and the legal height limits over time. Evidently, height limits that were in place between 1893 and 1920 were enforced and binding. Within a couple of years from the relaxation of height limits in 1920, a number of very tall buildings exceeding 100 meters was completed. The change in the zoning regime provides a plausible explanation for the sharp increase in height elasticity estimates displayed in Figure 8 in the main paper and Figure $\mathrm{A} 7$ in this appendix.

Fig. A8. Building heights vs. height limits over time

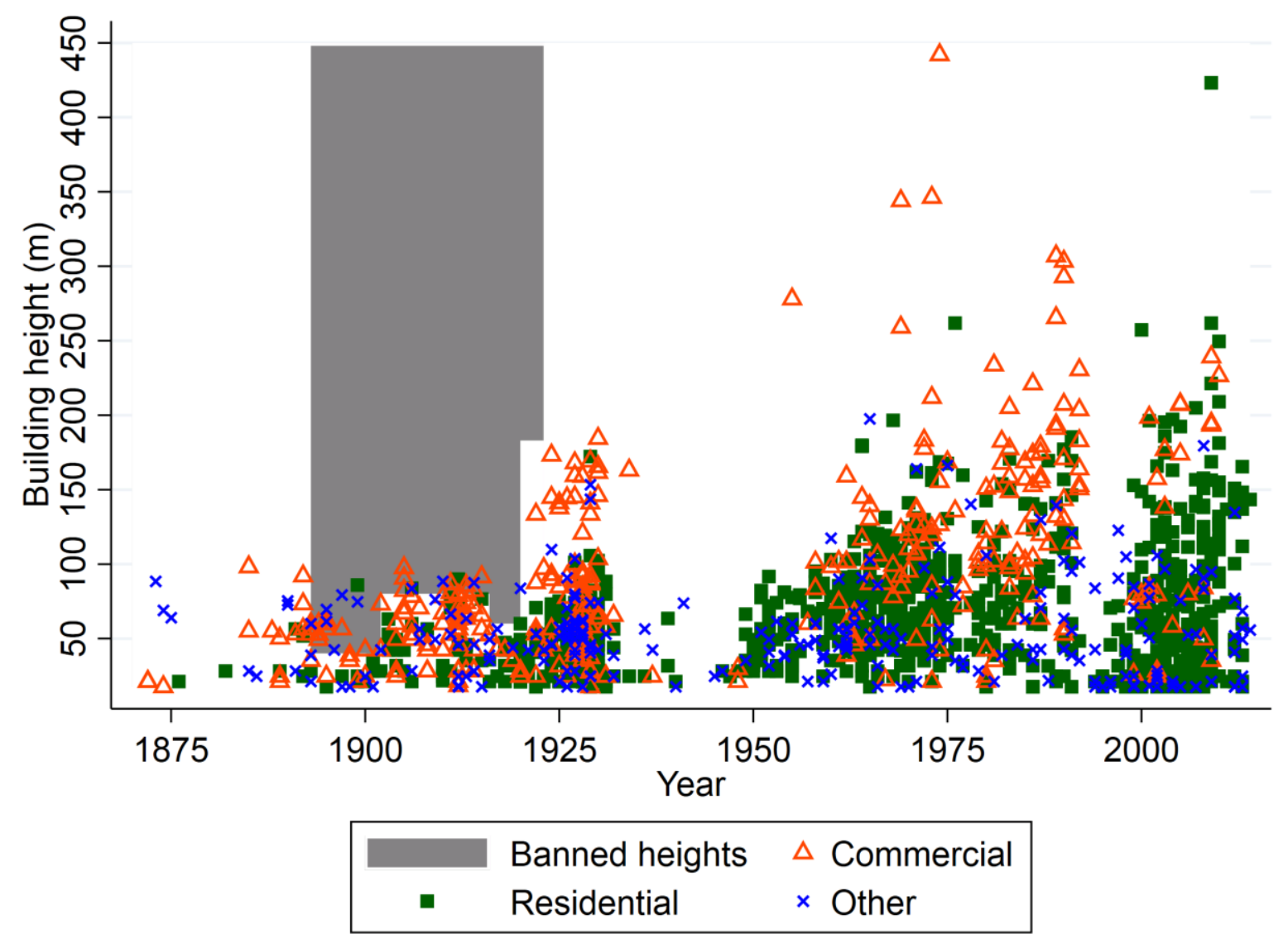

Notes: Own illustration based on the height limits reported in Barr (2013). Height data from Emporis.

It appears that some of the variation in the height elasticity over time can be attributed to changes in the zoning regime. Theoretically, the zoning ordinance in place since 1957 could also affect the spatial distribution of height elasticities if the FAR limits put implicit limits to building heights and the degree to which they were binding varied significantly across zoning districts. To analyze the relationship between the height elasticity and the FAR limits, we match our constructions data to a 
GIS map representing boundaries of zoning districts that is available at the Chicago Data Portal (https://data.cityofchicago.org). Via a zoning code, which identifies each type of zoning district, the zoning districts can be linked to the legally allowed FAR, which are defined in the Chicago Zoning Ordinance. We use the 2016 versions of the district map and the zoning ordinance for all constructions because the spatial variation greatly exceeds the temporal variation in FAR regulations.

The bottom-right panel of Figure A6 does not seem to point to a strong correlation between the LWR height elasticity estimates and legally allowed maximum FAR. In Table A5, we expand on the analysis focusing on constructions that occurred after 1957. We first regress the height elasticity estimates against land use indicators (1) and locational variables (2) before we use a full set of dummy variables, each of which indicates one of the various zoning district types (3-4) as well as combinations of both (5-6). In line with the results reported in the main paper (Table 5, Figure 8) and in appendix section 4.3 (Figure A6), our height elasticity estimates vary notably by land use category, but broader spatial trends are moderate at best. We do find statistically significant and economically meaningful differences in height elasticities by zoning type, but the differences are much reduced once we control for use and location. Overall, the differences in the estimated height elasticities across district types are relatively small and, in line with Figure A6, do not appear to be correlated with the FAR limit. If the FAR limits are binding, the effects on height decisions appears to be roughly comparable across the city. 
Tab A5. Height elasticity by zoning type

\begin{tabular}{|c|c|c|c|c|c|c|}
\hline & (1) & (2) & (3) & (4) & (5) & (6) \\
\hline & \multicolumn{6}{|c|}{ Elasticity of height with respect to land price } \\
\hline $\begin{array}{l}\text { Commercial use } \\
\text { (dummy) }\end{array}$ & $\begin{array}{l}0.173^{* * *} \\
(0.006)\end{array}$ & $\begin{array}{l}0.162^{* * *} \\
(0.007)\end{array}$ & & & $\begin{array}{l}0.173^{* * *} \\
(0.007)\end{array}$ & $\begin{array}{l}0.162^{* * *} \\
(0.007)\end{array}$ \\
\hline $\begin{array}{l}\text { Residential use } \\
\text { (dummy) }\end{array}$ & $\begin{array}{l}0.076^{* * *} \\
(0.004)\end{array}$ & $\begin{array}{c}0.077^{* * *} \\
(0.004)\end{array}$ & & & $\begin{array}{l}0.070^{* * *} \\
(0.004)\end{array}$ & $\begin{array}{l}0.070^{* * *} \\
(0.004)\end{array}$ \\
\hline Log distance to CBD & & $\begin{array}{c}-0.019^{* * *} \\
(0.003)\end{array}$ & & & & $\begin{array}{c}-0.026^{* * *} \\
(0.004)\end{array}$ \\
\hline $\begin{array}{l}\text { Log distance to Lake } \\
\text { Michigan }\end{array}$ & & $\begin{array}{c}-0.017^{* * *} \\
(0.006)\end{array}$ & & & & $\begin{array}{c}-0.022^{* * *} \\
(0.005)\end{array}$ \\
\hline Log distance to river & & $\begin{array}{l}-0.004 \\
(0.005)\end{array}$ & & & & $\begin{array}{l}-0.002 \\
(0.005)\end{array}$ \\
\hline FAR-0.5 & & & $\begin{array}{l}0.100^{* * *} \\
(0.001)\end{array}$ & $\begin{array}{l}0.100^{* * *} \\
(0.001)\end{array}$ & $\begin{array}{l}0.030^{* * *} \\
(0.004)\end{array}$ & $\begin{array}{l}0.004 \\
(0.005)\end{array}$ \\
\hline FAR-0.9 & & & $\begin{array}{c}0.026 \\
(0.031)\end{array}$ & $\begin{array}{c}0.012 \\
(0.041)\end{array}$ & $\begin{array}{l}-0.052 \\
(0.037)\end{array}$ & $\begin{array}{l}-0.050^{* *} \\
(0.024)\end{array}$ \\
\hline FAR-1.2 & & & $\begin{array}{l}0.059^{* * *} \\
(0.013)\end{array}$ & $\begin{array}{l}0.021^{*} \\
(0.011)\end{array}$ & $\begin{array}{l}-0.021^{* *} \\
(0.010)\end{array}$ & $\begin{array}{l}-0.021^{* *} \\
(0.009)\end{array}$ \\
\hline FAR-2 & & & $\begin{array}{l}0.096^{* * *} \\
(0.009)\end{array}$ & $\begin{array}{l}0.058^{* * *} \\
(0.006)\end{array}$ & $\begin{array}{l}-0.003 \\
(0.007)\end{array}$ & $\begin{array}{l}-0.013^{* *} \\
(0.006)\end{array}$ \\
\hline FAR-2.2 & & & $\begin{array}{l}0.208^{* * *} \\
(0.018)\end{array}$ & $\begin{array}{l}0.102^{* * *} \\
(0.011)\end{array}$ & $\begin{array}{l}0.045^{* * *} \\
(0.012)\end{array}$ & $\begin{array}{l}0.033^{* * *} \\
(0.012)\end{array}$ \\
\hline FAR-2.5 & & & $\begin{array}{l}0.012^{* * *} \\
(0.001)\end{array}$ & $\begin{array}{l}0.012^{* * *} \\
(0.001)\end{array}$ & $\begin{array}{l}-0.058^{* * *} \\
(0.004)\end{array}$ & $\begin{array}{l}-0.070^{* * *} \\
(0.005)\end{array}$ \\
\hline FAR-0.3 & & & $\begin{array}{l}0.187^{* * *} \\
(0.016)\end{array}$ & $\begin{array}{l}0.075^{* * *} \\
(0.011)\end{array}$ & $\begin{array}{c}(0.004) \\
0.012 \\
(0.011)\end{array}$ & $\begin{array}{l}(0.005 \\
0.005 \\
(0.008)\end{array}$ \\
\hline FAR-0.4 & & & $\begin{array}{l}0.080^{* * *} \\
(0.009)\end{array}$ & $\begin{array}{l}0.050^{* * *} \\
(0.006)\end{array}$ & $\begin{array}{l}-0.015^{*} \\
(0.008)\end{array}$ & $\begin{array}{c}-0.027^{* * *} \\
(0.007)\end{array}$ \\
\hline FAR-5 & & & $\begin{array}{l}0.197^{* * *} \\
(0.011)\end{array}$ & $\begin{array}{l}0.091^{* * *} \\
(0.008)\end{array}$ & $\begin{array}{l}0.026^{* * *} \\
(0.007)\end{array}$ & $\begin{array}{l}0.006 \\
(0.007)\end{array}$ \\
\hline FAR-6.6 & & & $\begin{array}{l}0.116^{* * *} \\
(0.006)\end{array}$ & $\begin{array}{l}0.098^{* * *} \\
(0.005)\end{array}$ & $\begin{array}{l}0.032^{* * *} \\
(0.006)\end{array}$ & $\begin{array}{c}0.000 \\
(0.006)\end{array}$ \\
\hline FAR-7 & & & $\begin{array}{l}0.191^{* * *} \\
(0.011)\end{array}$ & $\begin{array}{l}0.084^{* * *} \\
(0.009)\end{array}$ & $\begin{array}{l}0.024^{* * *} \\
(0.007)\end{array}$ & $\begin{array}{l}-0.012 \\
(0.008)\end{array}$ \\
\hline FAR-10 & & & $\begin{array}{l}0.122^{* * *} \\
(0.008)\end{array}$ & $\begin{array}{l}0.093^{* * *} \\
(0.008)\end{array}$ & $\begin{array}{l}0.031^{* * *} \\
(0.005)\end{array}$ & $\begin{array}{l}-0.015^{* *} \\
(0.007)\end{array}$ \\
\hline FAR-12 & & & $\begin{array}{l}0.176^{* * *} \\
(0.009)\end{array}$ & $\begin{array}{l}0.070^{* * *} \\
(0.008)\end{array}$ & $\begin{array}{c}0.009 \\
(0.006)\end{array}$ & $\begin{array}{c}-0.030^{* * *} \\
(0.007)\end{array}$ \\
\hline FAR-16 & & & $\begin{array}{l}0.152^{* * *} \\
(0.010)\end{array}$ & $\begin{array}{l}0.105^{* * *} \\
(0.009)\end{array}$ & $\begin{array}{l}-0.013^{*} \\
(0.007)\end{array}$ & $\begin{array}{c}-0.050^{* * *} \\
(0.008)\end{array}$ \\
\hline FAR-PD & & & $\begin{array}{l}0.166^{* * *} \\
(0.004)\end{array}$ & $\begin{array}{l}0.070^{* * *} \\
(0.005)\end{array}$ & $\begin{array}{l}0.008^{*} \\
(0.004)\end{array}$ & $\begin{array}{l}-0.016^{* * *} \\
(0.005)\end{array}$ \\
\hline Constant & $\begin{array}{l}0.160^{* * *} \\
(0.011)\end{array}$ & $\begin{array}{l}0.198^{* * *} \\
(0.013)\end{array}$ & $\begin{array}{l}0.146^{* * *} \\
(0.001)\end{array}$ & $\begin{array}{l}0.133^{* * *} \\
(0.013)\end{array}$ & $\begin{array}{l}0.153^{* * *} \\
(0.011)\end{array}$ & $\begin{array}{l}0.229^{* * *} \\
(0.015)\end{array}$ \\
\hline Cohort effects & Yes & Yes & - & Yes & Yes & Yes \\
\hline r2 & .718 & .739 & .167 & .548 & .767 & .793 \\
\hline $\mathrm{N}$ & 1073 & 1073 & 1039 & 1039 & 1039 & 1039 \\
\hline
\end{tabular}

Notes: The dependent variable is the location-time specific estimate of the height elasticity from LWR illustrated in Figure 8 in the main paper. Observations include constructions after the introduction of the modern zoning plan (in 1957). FAR-0.5 throughout to FAR-PD are dummy variables denoting zoning districts with the same height limit. A number following "FAR-" denotes the FAR limit in the district. FAR-PD indicates planned developments, where FARs are negotiated. The baseline zoning category is missing information. Robust standard errors are in parentheses. ${ }^{*} p<0.1,{ }^{* *} p<0.05,{ }^{* * *} p<0.01$.

\subsection{The effect of height on the ratio of usable over gross floor space}

In Table 6 of the main paper, we report estimates of the elasticity of average floor space construction costs with respect to height. These estimates are based on usable floor space as opposed to 
gross floor space to take into account that in taller buildings a larger fraction of floor space needs to be dedicated to facilities such as elevators. Because usable floor space is available for a smaller fraction of observations than gross floor space, we impute net floor space to prevent the already small samples in the construction cost models from shrinking further. Our imputation is based on the regression models reported in Table A6 whose results, however, are interesting in their own right. Given gross floor space and the estimates from TableA6, it is straightforward to impute usable floor space.

To estimate the rate at which the ratio of net over gross floor space declines in height, we regress the log difference between net and gross floor space against the log of height separately for small buildings with less than five floors as well as tall commercial and residential structures. We find no significant effect of height on usable floor space for small buildings, which is intuitive given that for such buildings the space dedicated to elevators or bearing structures does not depend much on height. In contrast, we find a sizable and significant elasticity for tall buildings. For commercial buildings, the ratio of net over gross floor space declines by about $0.09 \%$ for every $1 \%$ increase in height. The elasticity is more than twice as large for tall residential buildings. One explanation for this notable difference is that residential buildings typically have a smaller floor plate size as residential users require more exterior walls then commercial users (Smith et al., 2014). The smaller floor plate size implies that on every floor a similar space dedicated to elevators or bearing structures corresponds to a larger fraction at gross space.

Based on the results reported in Table A6, we impute the log net floor space simply by adding the height-dependent predicted log difference between net and gross floor space to a building's log gross floor space.

Tab A6. Height effects on usable floor space

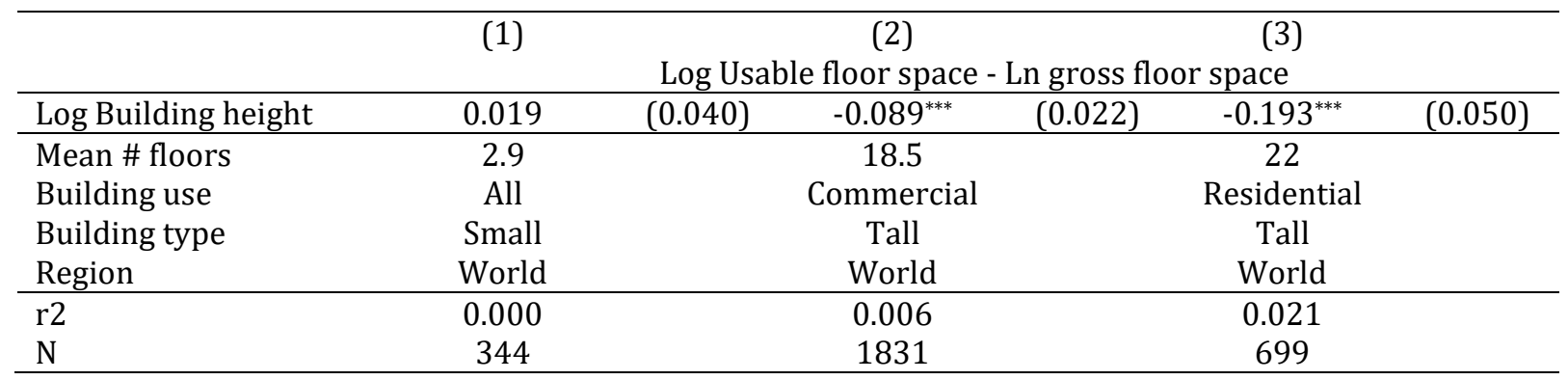

Notes: Data from Emporis. Small buildings have less than five floors. Tall buildings have five or more floors. For a small percentage of buildings height is imputed based on floors using an auxiliary regression of height against floors (on average height increases by 3.6 meters per floor). Robust standard errors in parentheses. ${ }^{*} p<0.1$, ${ }^{* *} p<0.05,{ }^{* * *} p<0.01$. 


\subsection{Pseudo Chicago sample}

One of the insights from Table 6 in the main paper is that the elasticity of floor space construction cost with respect to height is increasing in height. This is a concern because - due to data limitations

- we cannot estimate this parameter for Chicago, but must include wider areas which may result in a different height profile. In Figure A9 we illustrate the distribution of building heights in the Chicago sample used in our baseline analyses as well as the distributions in the "world" and "US" construction cost samples. Evidently, buildings in Chicago are notably taller than in an average city, confirming the notion of Chicago being a vertical city.

To generate a sample with a more similar height distribution, we conduct a propensity score matching using a biweight kernel. ${ }^{2}$ Using the resulting weights vector to reweight the sample of US buildings, we obtain the "Pseudo Chicago" sample, which indeed exhibits a height profile that is much closer to the actual Chicago. Thus, Figure A9 confirms that for our purposes the propensity score matching represents a reasonable second-best approach in the absence of sufficient actual data for Chicago.

\section{Fig. A9. Kernel density of height distributions}

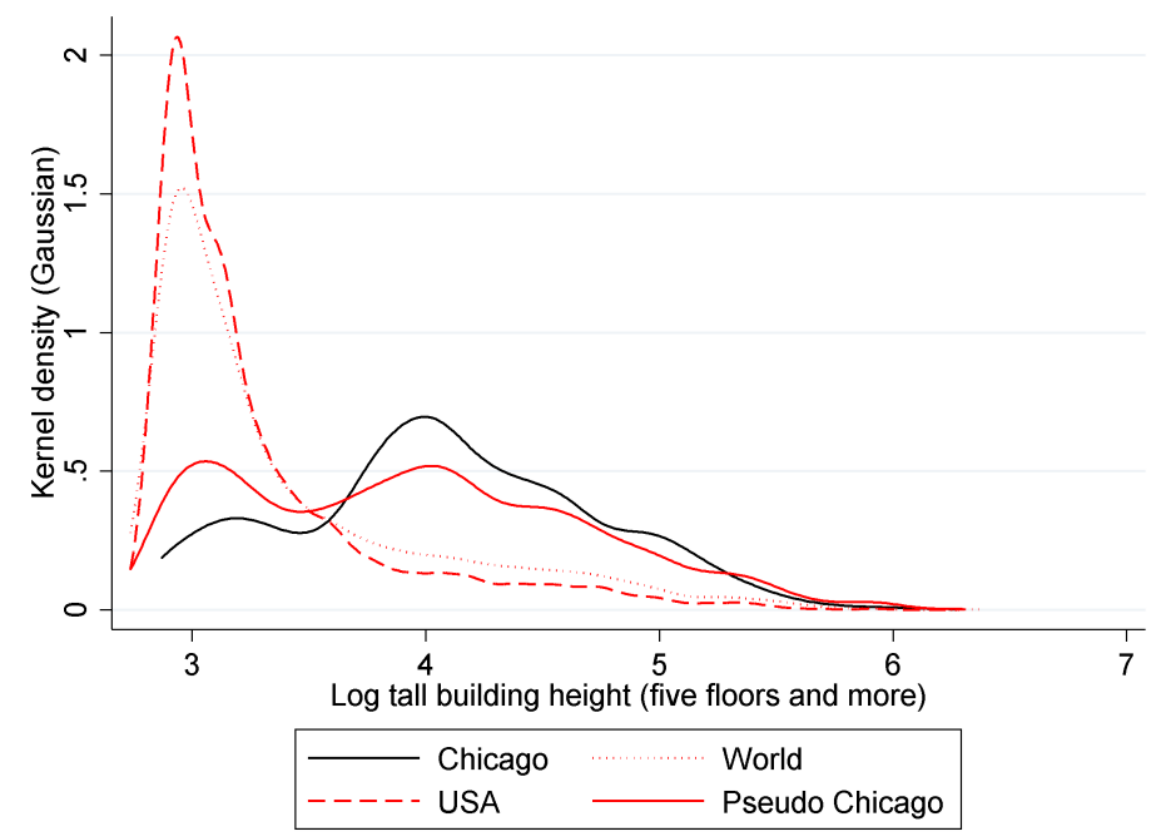

Notes: Data from Emporis.

\footnotetext{
${ }^{2}$ We use the user-written Stata module psmatch2 (Leuven and Sianesi, 2003).
} 


\subsection{Height effects on the floor area ratio of small residential buildings}

The focus of the analysis is on tall buildings, which are distinctively different from small buildings in the sense that residents are less likely to have direct preferences for land (similarly commercial users in tall buildings will not use land as an imputed factor). To analyze the extent to which our height elasticity estimates generalize to small residential structures, we conduct a complementary analysis using the 2003 assessment roll provided by the Cook County Assessor's Office. The data set covers the full cross-section of approximately 250 thousand small residential properties including information on floor and plot areas and construction dates. The data set also contains a local identifier (the pin) which makes it possible to merge the data to our land price data set (by parcel location and construction date).

Unfortunately, we do not observe the height of these building directly. Instead, we use the floor area ratio as an imperfect proxy. This is a notable limitation because if developers respond to increasing land prices by developing a larger fraction of land, the floor area ratio will vary less than height across locations. Therefore, an estimate of the floor area ratio with respect to land price is an upperbound estimate of the height elasticity.

In Table A7 we present a series of estimates of the elasticity of floor area ratio with respect to height for small residential buildings. Similar to Table 5 in the main paper, we allow for an interaction with a time trend (with 2000 being the base year). We find a 2000 elasticity of 0.2 across all small residential buildings in column (1), which is notably smaller than the height elasticity we estimate for tall residential buildings. However, there is significant heterogeneity. In the subsequent columns, we split the sample at the median of the distributions of floor area ratio and land price. For small properties in the denser and more expensive areas we find a floor area ratio elasticity that is similar to the height elasticity estimated for tall residential buildings. This result suggests that the mechanisms emphasized in our simple theory generalizes to a relatively large sample of non-tall structures in relatively dense and expensive areas. For small properties in relatively low-density and inexpensive areas, however, the floor area ratio elasticity is close to and not significantly different from zero. This finding is intuitive given that these parcels likely consist of single-family houses to which our theoretical framework does not apply. 
Tab A7. The elasticity of floor area ratio with respect to land price for small residential properties

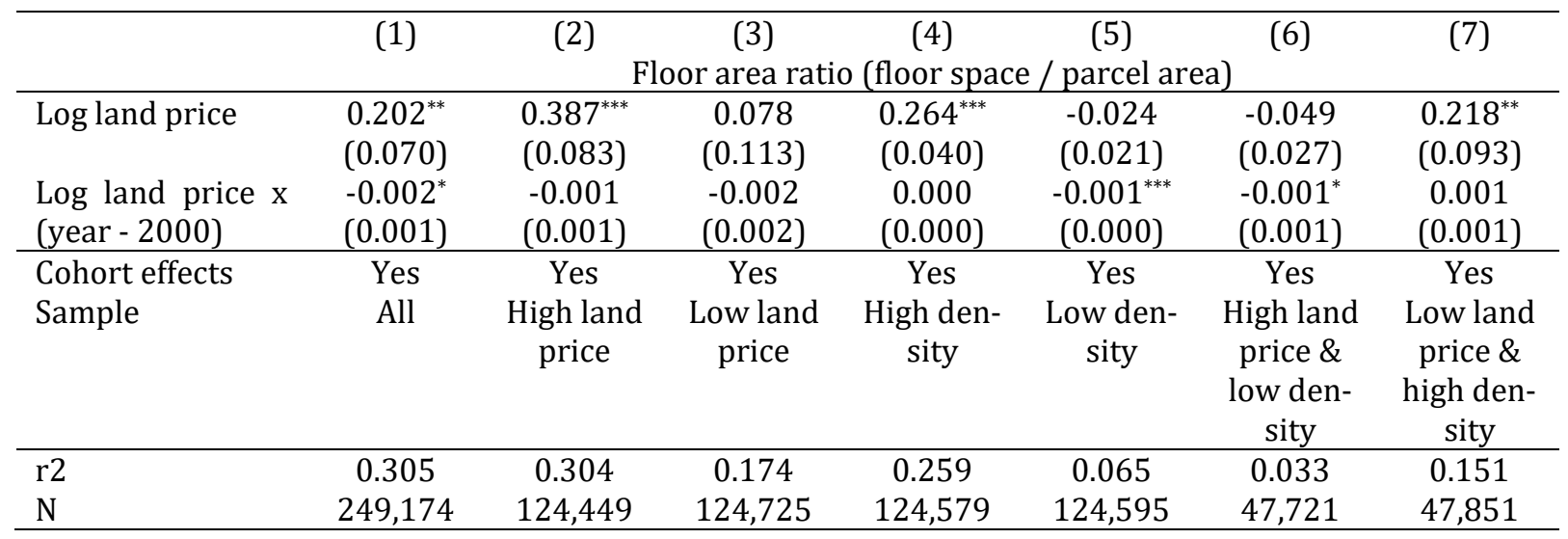

Notes: Data from the Cook County Assessor's Office (2003 assessment roll). High land price parcels are parcels with an above median land price within (decade) construction cohorts. High density parcels are parcels with an above median floor area ratio. Standard errors clustered on cohort effects are in parentheses. ${ }^{*} p<0.1,{ }^{* *} p<$ $0.05,{ }^{* * *} p<0.01$

Unlike for the elasticity of height with respect to land price for tall buildings, we do not find that the elasticity increases over time. This result is in line with innovations in construction technology concerning elevators, steel frame, or the use of reinforced concrete, primarily affecting the construction cost of tall buildings. Minimally, the effects of reductions in the cost of height over time are more than compensated for by increasing preferences for exterior spaces (land), which presumably play a more important role for residents living in single-family houses than in apartments in tall residential buildings.

\section{References}

Ahlfeldt, G. M., Möller, K., Waights, S., \& Wendland, N. (2012). One Hundred Years of Land Value. Data Documentation. Olcott's Land Values for Chicago (1913 - 1990) Retrieved from http://www.ahlfeldt.com/OLCOTT.pdf

Barr, J. (2013). Skyscrapers and skylines: New York and Chicago, 1885-2007. Journal of Regional Science, 53(3), 369-391.

Ferry, D., \& Brandon, P. (1980). Cost Planning of Buildings. London: Granada.

Hoyt, H. (1933). One hundred years of land values in Chicago. Chicago: Chicago University Press.

Leuven, E., \& Sianesi, B. (2003). PSMATCH": Stata module to perform full Mahalonobis and propensity score matching, common support graphing, and covariate imbalance testing. http://ideas.repec.org/c/boc/bocode/s432001.html, Version 1.2.3.

Liu, C. H., Rosenthal, S. S., \& Strange, W. C. (2015). The Vertical City: Rent Gradients and Spatial Structure. Working Paper.

Seeley, I. (1983). Building Economics. London: Macmillan.

Silverman, B. W. (1986). Density Estimation For Statistics and Data Analysis. Monographs on Statistics and Applied Probability.

Smith, B., Dholakia, M., \& Heseltine, R. (2014). Cost model: Tall buildings. Building. 